Portland State University

PDXScholar

\title{
Matching the Speed of Technology with the Speed of Local Government: Developing Codes and Policies Related to the Possible Impacts of New Mobility on Cities
}

\author{
Marc Schlossberg \\ University of Oregon \\ Heather Brinton \\ University of Oregon
}

Follow this and additional works at: https://pdxscholar.library.pdx.edu/trec_reports

Part of the Transportation Commons, Urban Studies Commons, and the Urban Studies and Planning Commons

Let us know how access to this document benefits you.

\section{Recommended Citation}

Schlossberg, Marc and Heather Brinton. Matching the Speed of Technology with the Speed of Local Government: Developing Flexible Codes and Policies Related to the Possible Impacts of Autonomous Vehicles on Cities. NITC-RR1216 Portland, OR: Transportation Research and Education Center (TREC), 2020. https://dx.doi.org/10.15760/trec.251

This Report is brought to you for free and open access. It has been accepted for inclusion in TREC Final Reports by an authorized administrator of PDXScholar. Please contact us if we can make this document more accessible: pdxscholar@pdx.edu. 
TRANSPORTATION and COMMUNITIES

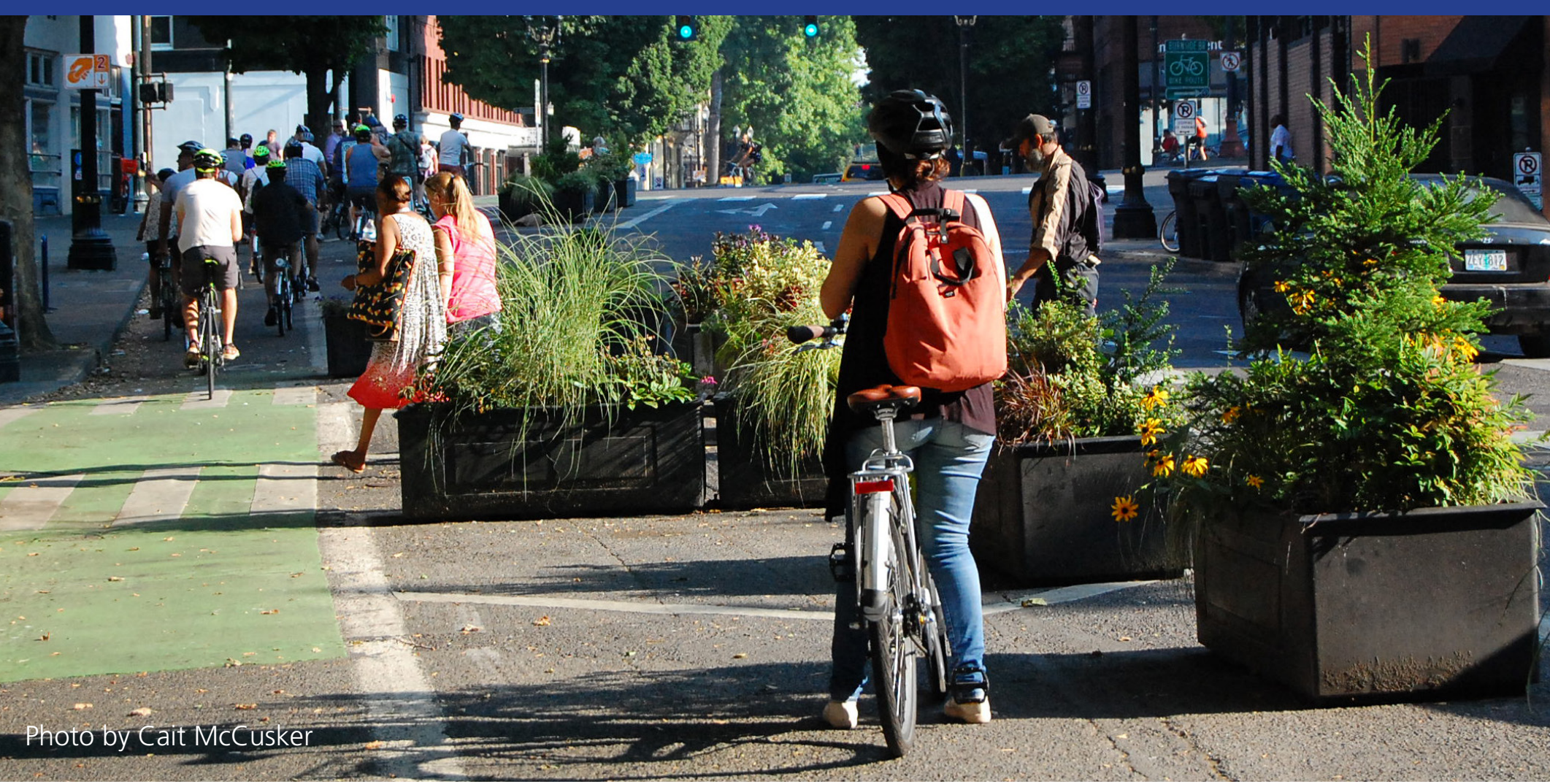

\section{Matching the Speed of Technology with the Speed of Local Government: Developing Codes and Policies Related to the Possible Impacts of New Mobility on Cities}

Marc Schlossberg, Ph.D. Heather Brinton

\section{$\mathbf{O}$ OREGON}




\title{
MATCHING THE SPEED OF TECHNOLOGY WITH THE SPEED OF LOCAL GOVERNMENT
}

\section{Developing Codes and Policies Related to the Possible Impacts of New Mobility on Cities}

\author{
Final Report \\ NITC-RR-1216 \\ by \\ Marc Schlossberg, Professor \\ Department of Planning, Public Policy and Management \\ University of Oregon \\ Heather Brinton, Director \\ Environment and Natural Resources Law Center \\ University of Oregon \\ for \\ National Institute for Transportation and Communities (NITC) \\ P.O. Box 751 \\ Portland, OR 97207
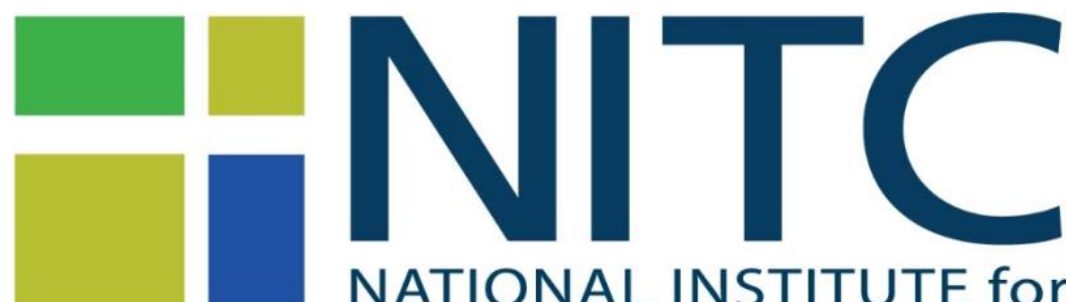 \\ NATIONAL INSTITUTE for \\ TRANSPORTATION and COMMUNITIES
}

June 2020 


\begin{tabular}{|c|c|c|c|c|c|}
\hline \multicolumn{6}{|c|}{ Technical Report Documentation Page } \\
\hline $\begin{array}{l}\text { 1. Report No. } \\
\text { NITC-RR-1216 }\end{array}$ & \multicolumn{3}{|c|}{ 2. Government Accession No. } & \multicolumn{2}{|c|}{ 3. Recipient's Catalog No. } \\
\hline \multirow{2}{*}{\multicolumn{4}{|c|}{$\begin{array}{l}\text { 4. Title and Subtitle } \\
\text { Matching the Speed of Technology with the Speed of Local Government: } \\
\text { Developing Codes and Policies Related to the Possible Impacts of New } \\
\text { Mobility on Cities }\end{array}$}} & \multicolumn{2}{|c|}{$\begin{array}{l}\text { 5. Report Date } \\
\text { June } 2020\end{array}$} \\
\hline & & & & \multicolumn{2}{|c|}{$\begin{array}{l}\text { 6. Performing Organization } \\
\text { Code }\end{array}$} \\
\hline \multicolumn{4}{|l|}{$\begin{array}{l}\text { 7. Author(s) } \\
\text { Marc Schlossberg } \\
\text { Heather Brinton }\end{array}$} & \multicolumn{2}{|c|}{$\begin{array}{l}\text { 8. Performing Organization } \\
\text { Report No. }\end{array}$} \\
\hline \multirow{2}{*}{\multicolumn{4}{|c|}{$\begin{array}{l}\text { 9. Performing Organization Name and Address } \\
\text { University of Oregon } \\
1209 \text { University of Oregon } \\
\text { Eugene, OR } 97403\end{array}$}} & \multicolumn{2}{|c|}{ 10. Work Unit No. (TRAIS) } \\
\hline & & & & \multicolumn{2}{|c|}{ 11. Contract or Grant No. } \\
\hline \multirow{2}{*}{\multicolumn{4}{|c|}{$\begin{array}{l}\text { 12. Sponsoring Agency Name and Address } \\
\text { National Institute for Transportation and Communities (NITC) } \\
\text { P.O. Box } 751 \\
\text { Portland, Oregon } 97207\end{array}$}} & \multicolumn{2}{|c|}{$\begin{array}{l}\text { 13. Type of Report and } \\
\text { Period Covered }\end{array}$} \\
\hline & & & & \multicolumn{2}{|c|}{ 14. Sponsoring Agency Code } \\
\hline \multicolumn{6}{|c|}{ 15. Supplementary Notes } \\
\hline \multirow{2}{*}{\multicolumn{6}{|c|}{$\begin{array}{l}\text { 16. Abstract } \\
\text { Advances in transportation technology such as the advent of scooter and bikeshare systems } \\
\text { (micromobility), ridehailing, and autonomous vehicles (AV's) are beginning to have profound effects not } \\
\text { only on how we live, move, and spend our time in cities, but also on urban form and development itself. } \\
\text { These new technologies are changing the systems of transport, the layout of cities, and the places we } \\
\text { spend our time. In turn, these changes will likely have additional and profound effects on land use, street } \\
\text { design, parking, housing, equity, municipal finance, and fundamental issues related to urban density, } \\
\text { sprawl, vitality and the economic viability and sustainability of communities of all sizes. } \\
\text { These technological changes are being introduced much faster than how local government code and } \\
\text { policy typically react, especially because the issues at play and their possible impact remain almost } \\
\text { entirely outside the knowledge base or skill set of the vast majority of city staff or leadership. This report, } \\
\text { thus, is a guide to communities of all sizes on how to adopt local policy and code to both respond to the } \\
\text { emergence of these technologies and encourage their responsible propagation, as they all hold } \\
\text { tremendous positive opportunities for cities that are serious about decarbonizing, as well as issues of } \\
\text { equity, public health, freedom, household affordability, and more. }\end{array}$}} \\
\hline & & & & & \\
\hline \multicolumn{2}{|c|}{$\begin{array}{l}\text { 17. Key Words } \\
\text { Transportation, new mobility, scooters, micromobility, } \\
\text { bikeshare, TNC, ridehailing, autonomous vehicle, policy, } \\
\text { code }\end{array}$} & \multicolumn{4}{|c|}{$\begin{array}{l}\text { 18. Distribution Statement } \\
\text { No restrictions. Copies available from NITC: } \\
\text { www.nitc-utc.net }\end{array}$} \\
\hline $\begin{array}{l}\text { 19. Security Classification (of this } \\
\text { report) } \\
\text { Unclassified }\end{array}$ & $\begin{array}{l}\text { 20. Security Classifica } \\
\text { this page) } \\
\text { Unclassified }\end{array}$ & & & o. of Pages & 22. Price \\
\hline
\end{tabular}




\section{ACKNOWLEDGEMENTS}

This project was funded by the National Institute for Transportation and Communities (NITC; grant number NITC-RR-1216 (2106DR-39973)), a U.S. DOT University Transportation Center. All dissemination should include the NITC logo and reference as a sponsoring agency.

We would also like to acknowledge several people who provided significant input into this project, including students Sid Hariharan (Planning), Ben Molloy (Law), John Quinto (Law), Christopher Groesbeck (Planning and Law), and two, law-based research associates: Douglas Quirke and Michelle Smith.

\section{DISCLAIMER}

The contents of this report reflect the views of the authors, who are solely responsible for the facts and the accuracy of the material and information presented herein. This document is disseminated under the sponsorship of the U.S. Department of Transportation University Transportation Centers Program in the interest of information exchange. The U.S. Government assumes no liability for the contents or use thereof. The contents do not necessarily reflect the official views of the U.S. Government. This report does not constitute a standard, specification, or regulation.

In addition, the subject matter discussed in this report - local policies that relate to new mobility - are changing daily as new cities figure out their own approach to these transportation shifts, learn from other communities' experiences, and as private sector providers work on regulatory frameworks with policy makers. Thus, the information presented in this report represents a modern snapshot as of the time of publication, but there will no doubt be new policies to draw from that will have be adopted subsequent to this publication. For new policy and code developments, we suggest a resource launched in early 2020, The Nexus, which is a continuously updating clearinghouse of policies, research, and other related information at the intersection of new mobility and urban form and function. More information can be found here:

https://www.urbanismnext.org/the-nexus.

\section{RECOMMENDED CITATION}

Schlossberg, Marc and Heather Brinton. Matching the Speed of Technology with the Speed of Local Government: Developing Flexible Codes and Policies Related to the Possible Impacts of Autonomous Vehicles on Cities. NITC-RR1216 Portland, OR:

Transportation Research and Education Center (TREC), 2020. 


\section{TABLE OF CONTENTS}

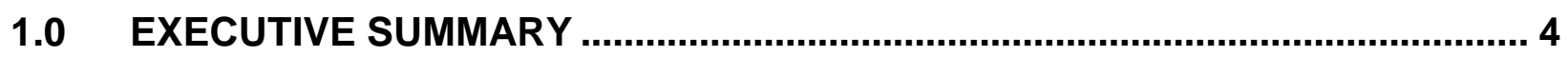

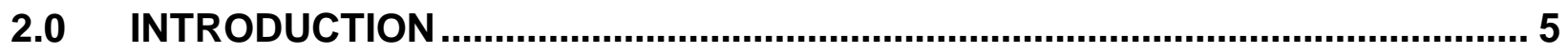

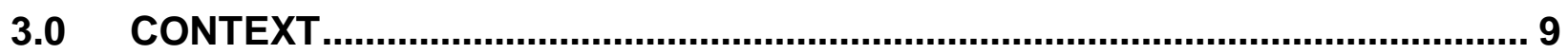

4.0 GENERAL PRINCIPLES FOR MUNICPAL TRANSPORTATION

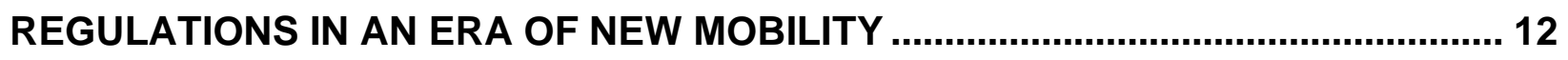

4.1 COMMUNITY GOALS AND MODAL PRIORITIES AS DRIVERS OF MOBILITY

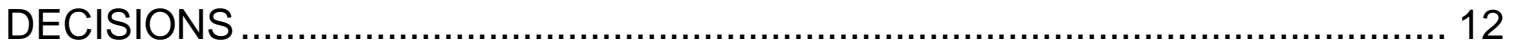

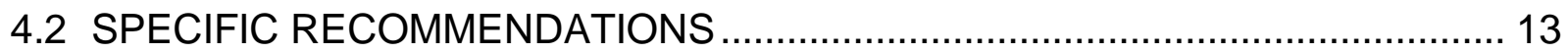

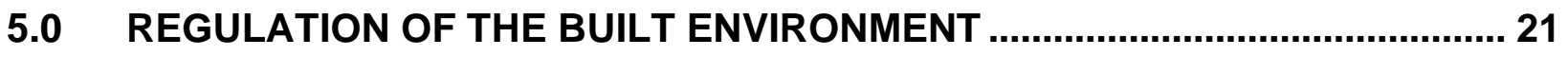

5.1 MANAGEMENT OF THE CURB FOR MORE THAN ON-STREET PARKING ... 21

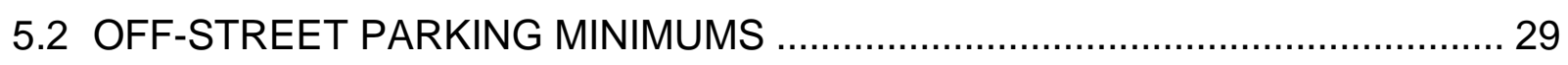

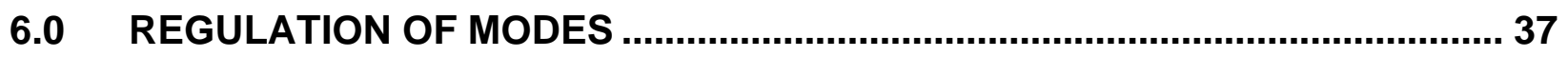

6.1 FLEXIBLE REGULATION VIA PILOT PROGRAMS ............................................ 37

6.2 MICROMOBILITY: BICYCLES AND SCOOTERS …....................................... 38

6.3 TRANSPORTATION NETWORK COMPANIES ........................................... 45

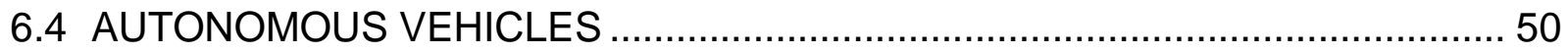

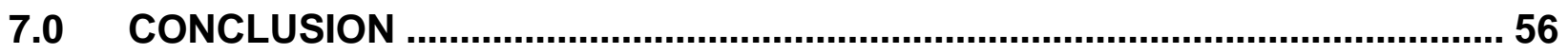

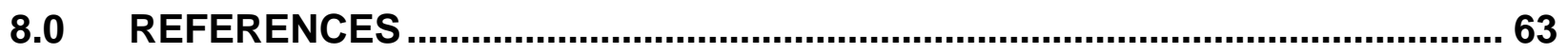

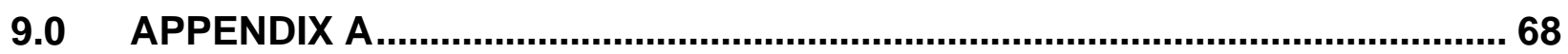




\subsection{EXECUTIVE SUMMARY}

Advances in transportation technology such as the advent of scooter and bikeshare systems (micromobility), ridehailing, and autonomous vehicles (AV's) are beginning to have profound effects not only on how we live, move, and spend our time in cities, but also on urban form and development itself. These new technologies are changing the systems of transport, the layout of cities, and the places we spend our time. In turn, these changes will likely have additional and profound effects on land use, street design, parking, housing, equity, municipal finance, and fundamental issues related to urban density, sprawl, vitality and the economic viability and sustainability of communities of all sizes.

These technological changes are being introduced much faster than how local government code and policy typically react, especially because the issues at play and their possible impact remain almost entirely outside the knowledge base or skill set of the vast majority of city staff or leadership. This report, thus, is a guide to communities of all sizes on how to adopt local policy and code to both respond to the emergence of these technologies and encourage their responsible propagation, as they all hold tremendous positive opportunities for cities that are serious about decarbonizing, as well as issues of equity, public health, freedom, household affordability, and more. 


\subsection{INTRODUCTION}

Over the last twenty years, there has been a noticeable shift in local transportation priorities as both millennials and retiring baby boomers seek out more urban neighborhoods where vehicular ownership is not required or desired for nearly every household trip. Cities first began (re)investing in light rail and bus rapid transit and updating land use policies to achieve denser, more mixed-use urban nodes. Over the last ten years, bikeshare systems and bicycle infrastructure investments in cities all across the country have made biking more appealing to more people by making it safer and easier, resulting in a significant increase in the number of bike trips in these cities. And over the last three years, the emergence of transportation network companies (TNCs) (also commonly referred to as ride-hailing services), bikeshare, and scootershare have radically altered the way millions of local transportation trips happen. With autonomous vehicles on the horizon, additional shifts of both transportation utilization are likely. These new technologies are beginning to change snot only the systems of transport, but the layout of cities, and the places we spend our time, and many anticipate an accelerating pace of change as these new forms of transportation begin substituting for existing dominant modes of transport. The impacts of new transportation on the spatial form and function of cities are anticipated to be significant.

In legal terminology (our research team represents both law and planning), the transportation changes of the last twenty years, including the rapid changes of the last few, have created new transportation "fact patterns." When new fact patterns emerge, existing legal frameworks can become outdated and no longer support societal decision making as best as possible. Given these new fact patterns around local transportation behavior, new legal approaches to help govern the changes are needed. This report aims to help cities quickly update their local code and policy based on the new circumstances they are experiencing.

These technological changes are being introduced much faster than local government code and policy can typically react, especially because the issues at play and their possible impact remain almost entirely outside the knowledge base or skill set of the vast majority of city staff or leadership. The goal of this project is to investigate how some cities are proactively responding to these transportation changes, the common barriers they face, and model policy and code provisions that cities can largely adapt and adopt quickly to proactively ensure that local communities' responses to these technological transformations are consistent with overarching community values and goals.

Addressing new and quickly-evolving transformative circumstances is challenging for local policymakers, especially when it comes to anything that may impact the use of the street. Most people in most communities have lived their entire lives where car-based transport is the only practical, efficient mode of navigating low-density homogeneous land uses. Yet, there is an anticipated decline in owner-occupied automobile usage due to new forms of transportation options such as TNCs, bikeshare, scootershare, and autonomous vehicles. These new technologies, therefore, may require changes to the 
street in order to operate efficiently. Yet, action that local politicians or city staff currently make to alter the use of the street to make it easier to walk, scooter, bike, use transit, or ridehail almost always receives a public reaction against it, especially if it involves any reduction in car parking. The difference with the current mobility technologies is that they might help create a political space within which policymaking may be easier and public push back may decline. For example, if parking declines because more people are buying rides instead of using and parking their own vehicles, then repurposing a parking lot or parking lane may be politically easier because the space is not otherwise being utilized. What is key from our point of view is that cities begin to be prepared for these changes, adopting codes and policies that can meet their current realities while preparing them to quickly adapt to changing community patterns as these new transportation modes start having societal ripple effects.

The coming disruption could essentially have three waves:

1) current state, with both experimentation and lack of clarity about transportation changes;

2) five-to-twenty years of an expansion of small-footprint, low-carbon transport like bikeshare or scootershare (aka microbility), new models of ride hailing, innovations in transit and microtransit including autonomous versions, and autonomous vehicles more generally; and

3) a transformed transportation system where cities could need $90 \%$ fewer parking spaces and significantly less road space to meet local transportation demands, or, alternatively, cities with exacerbated urban sprawl and its attendant negative environmental, social, and health externalities.

We see two primary domains for regulation related to new mobility: 1) regulation of the built environment related to new forms of mobility; and 2) regulation of the mobility modes themselves. In terms of the built environment, new mobility modes are already altering and are likely to continue to alter patterns of individual movement, as well as how cities and their infrastructure are being utilized. In terms of the built environment, we focus on the following regulatory areas for cities:

- Street Right of Way (ROW). How might the allocation of lane space in the existing street right of way be responsive to rapid changes in transportation modal shifts?

- Regulation of the Curb. How should this 'new' resource be managed or priced to match community policy goals?

- On and Off-Street Parking. How might land currently used for parking be managed flexibly so that it can be repurposed more quickly for other uses?

- Land Use. How might changes in transportation options alter the urban form itself and how might general land use policy be utilized to support these shifts? 
In terms of the transportation modes themselves, there are generally three types of new mobility we are including in this report:

- Bike and Scooter Sharing. These small-footprint, low- or zero-carbon modes of transport have radically increased in usage over the last decade with the creation of both public and private-sector systems, pushing the need for better infrastructure for both movement and parking.

- Transportation Network Companies (TNCs). Ride-hailing services, connecting passengers with drivers for door-to-door trips, has grown with the expansion of providers such as Uber and Lyft. In addition to general transportation issues such as vehicle miles traveled (VMT), congestion, and parking, TNCs impact the use of curb space for pickup and drop-off of passengers in new ways in most cities in which they operate.

- Autonomous Vehicles (AVs). The future of AVs, in terms of ownership model, timeline for market penetration, and VMT impact is still unknown, yet provides major opportunities for cities to rethink how street space is used for vehicular movement, and how land is used for vehicular storage.

All of these new transportation technologies have the potential, if properly addressed by local governments, to further various community goals, including those related to sustainability, emission and congestion reduction, equity, community revitalization, etc. For example, TNCs and AVs have the potential to offer more equitable car-based transport that uses less land and results in lower carbon emissions. But these technologies can also be permitted in ways that result in continued transportation inequity, more congestion, and higher emissions. If TNCs and AVs are largely electric and shared (as opposed to transporting one passenger at a time), they are more likely to contribute to emission and congestion-reduction goals; on the other hand, if $\mathrm{AVs}$ are primarily owned by individuals as replacements for individually-owned non-AVs, the emission, congestion, and sprawl consequences of the status quo may be significantly exacerbated.

In terms of how policy turns into action administratively, it is also important to understand the different areas where regulations, policies, administrative rules, etc. impact the types of actions that might happen locally, the level of public input required or not, and what actions are subject to appeal or not. It is very likely the case that no two cities are exactly alike in terms of governance structure, and it will therefore vary from city-to-city how a particular change in policy or practice is implemented, and who at the city is legally responsible for implementing that change. In some cities, the discretion to implement a particular change may reside with an individual (whether it's the mayor, city manager, traffic engineer, director of transportation, et al.); in other cities the discretion to implement that same change may reside with a body (e.g., the city council, planning commission, subcommittee, etc.). It will also vary from city-to-city what type of process must be followed to implement a particular change in terms of public notice, public comment, etc. These variations in governance structure will invariably influence the pathway chosen to achieve a particular result. For example, it may be less 
time consuming/more efficient to implement changes in policy or practice on a limited duration/temporary basis that perhaps can be repeatedly renewed (and adjusted based on actual experience) than to do so via a more permanent policy or practice. Because of this variation in governance structure, it is outside the scope of this report to list the mechanics of how to implement a particular policy or code in your city. In fact, it may be the case that your city wishes to adapt a particular model policy to a code provision, or to use a particular model code provision as the basis for a pilot program that does not involve the enactment of new city code.

The real question from our perspective is whether these new transportation technologies provide unique opportunities for local municipalities to pivot from a transportation system based largely on single-occupancy vehicle use to a truly multimodal, space-efficient system where multiple community goals around land use, transportation, environment, equity, health, and economy can be met. The knowledge about how to make such shifts in our individual and collective transportation modal choices already exists, but the political hurdles remain; yet these new transportation technologies have the potential to open up new conversations about doing things differently.

This project is aimed at helping local communities enhance their ability to align their community values around economy, environment, and quality of life with mobility policy through this currently-unfolding transportation disruption by matching the speed of local decision making with the speed of technological disruption. The report that follows provides examples of experimentation from around the United States around these issues, frames these issues in larger municipal decision making, and provides model policy and code that communities can use or adapt for their own contexts.

The sample policies listed and described below were generated through continuous national scans of reports, news items, webinars, and conference presentations on the topic of new mobility and city planning. Resources from various compilers of latest developments were referenced, including Urbanism Next, Shared Use Mobility Center, and Three Revolutions among others. In the end, many of the codes and policies highlighted below derive from a small number of key west coast cities such as Seattle, Portland, San Francisco, and Los Angeles. While we were conscious about representing a broader array of cities in this policy discussion, we were primarily focused on the best policies and it is these west coast cities that have taken the national lead on the topic at hand. Inevitably, new city (and state) policies will be frequently developed, sometimes built on the policies listed here and sometimes developed anew, and we recommend referencing The Nexus, which is a continuously updating clearinghouse of policies, research, and other related information at the intersection of new mobility and urban form and function, for new developments (https://www.urbanismnext.org/the-nexus). 


\subsection{CONTEXT}

The urban form of cities generally corresponds to the transportation technology of the era during which that part of the city developed, with older areas sometimes being retrofitted to take advantage of newer technologies (Hanson and Giuliano 2004). During the walking era for example, cities were compact, and during the auto era they tended to sprawl. During transit eras, development tended to concentrate along rail corridors and around key transit stops. While most U.S. cities are still largely in the auto era in terms of urban form, land use policy, and street design, the era of car-based urban form began to diminish somewhat in the early part of this century. For the last twenty years, transit-oriented development, via light rail and bus rapid transit, became a normalized way to refocus urban development within existing urbanized space. And over the last five years, bikeshare and scootershare systems, in conjunction with doorto-door car-based transportation provided by TNCs, has opened up additional opportunities for urban infill as a desirable alternative to the contrasting pattern of urban expansion via low-density single-family housing and its associated privately-owned automobile dependency. These technology and urban form shifts have both driven and, at the same time, been driven by changes in demographic preferences for urban life, with more young professionals and recently-retired adults expressing interest in living in non-car-dependent neighborhoods.

Changes to the built environment and transportation usage often come about despite local policy and code, not because of it, however. The continued existence of minimum car parking requirements, for example, and policies supporting the primary role of the street as moving as many vehicles through space as quickly as possible, remain outdated and unresponsive to shifting lifestyle demands. And it is within this transitional space of old policy and new transportation behaviors that micromobility, TNCs, and soon AVs are inserting themselves.

In terms of micromobility, bicycle usage has been going through a steady increase over the last twenty years, rising 51\% for work trips from 2000 to 2016 (The League of American Bicyclists 2017). Shared micromobility (bike and scooter) utilization has experienced meteoric growth in the U.S. since 2010, increasing from around 321,000 trips in 2010 to eighty-four million trips in 2018, with 2018 trips more than double the number of micromobility trips made the previous year (National Association of City Transportation Officials 2018). The increase in bike and scooter use reveals a preference for small footprint, low-carbon, short-distance trips. In a recently-completed study of scooter use in Oakland, one million trips were recorded in the first six months, with and average trip length of 1.2 miles (City of Oakland Department of Transportation 2019), which is important given that $42 \%$ of trips under one mile and $67 \%$ of trips under three miles in the U.S. are via motorized vehicle (Litman 2017). 
TNC ridership has increased from an insignificant amount in 2012 to ridership of 1.8 billion in 2016 and 3.2 billion in 2018 (Schaller Consulting 2019). TNC VMT for 2018 was " 18.1 billion miles, which includes 11.8 billion miles carrying passenger(s) and 6.3 billion miles between trips" (Schaller Consulting 2019). The latest research on TNC usage in six major U.S. cities shows TNC trips constitute up to $2.9 \%$ of VMT in these metropolitan regions, and up to $13.4 \%$ of VMT in core urban areas. (Fehr \& Peers $2019 \mathrm{~b})$. This study also shows $38 \%$ to $54 \%$ of TNC VMT is without any passengers (between pickups or en route to a pickup).

While there remains many unknowns about the business model for AVs (e.g., will we own them individually or instead buy rides from a car service when we need one?), local city policy will play a tremendous role in whether AVs exacerbate the urban sprawl of the last seventy years or are part of a comprehensive approach to more efficiently and effectively utilize existing urbanized land and achieve better health, environmental, social, equity, and economic outcomes.

Some forecast that AVs will lead to a dramatic alteration of travel patterns, including an increase in trip generation rates, increases in VMT, and potential shifts in mode choice (Bierstedt 2014; Childress 2014; Fagnant 2015; Fagnant 2016; Schoettle and Sivak 2014). AV and particularly fleet $A V$ adoption may significantly reduce or eliminate the need for parking in ways we traditionally haven't seen (International Transport Forum 2015; Zhang 2015), representing big shifts in the largest single land use in most urban areas (Shoup 2005). VMT is expected to grow dramatically with individually-owned AVs, but only moderately with shared fleets of AVs (Bierstedt 2014; Childress 2014; Fagnant 2015; Fagnant 2016; Schoettle and Sivak 2014). And while it is unknown if individuals will relinquish car ownership as they are confronted with an autonomous ride-hailing vehicle and potential wait times, privacy concerns, and unknown reliability of services (Litman 2016), the use of fleets versus individual ownership would dramatically reduce the number of cars in the U.S. by as much as $90 \%$ (Fagnant 2014) and reduce the need for parking and its associated effects on development density and mixing of uses (Chapin 2016; Fagnant 2014; International Transport Forum 2015; Zhang 2015).

Parking decreases in particular will impact land use, street design, and development densities. This in turn will alter land values, residential and commercial location preferences, and ultimately overall development form and the mobility options that are the best fit in these new environments. It is exactly these types of downstream implications that local policy and codes generally try to regulate as they directly relate to city form and function, multi-modal mobility, the well-being of residents, and regional economic competitiveness. Yet, generally speaking, cities are unprepared for these changes as there is a lack of attention by local policymakers and researchers due to a general sense that AV implementation will occur in the distant future (Guerra 2016; Bell 2016). A cursory national scan of the advent of scooters and TNCs reveals that cities have struggled and continue to struggle with how to integrate them into their transportation mix, regulate them to achieve positive outcomes and limit negative ones, and understand larger changes to street design and land use code that may be required to take full advantage of their positive potential. 
New mobility modes (TNCs, shared bikes and scooters, AVs) represent a major revealed demand for transportation options that not only did not really exist a decade ago, but that no one predicted. These modes are not based on individually-owned and operated vehicles, thereby disconnecting trip-making and vehicle ownership for millions of trips annually and opening up new ways for households to think about their transportation and budgetary needs. It is not surprising that local policy and code were outdated and mismatched to these modes when they appeared. However, the fact remains that to be responsive to these shifts, cities must update local code and policy as quickly as possible, and there should be an openness to crafting new policy and code in ways that can accommodate other new transportation technologies as they emerge. This requires that code and related regulatory provisions be adaptable in a way that has not been required before. The key in crafting such flexible code is that it remains connected to core community values and goals, rather than to the transportation technology itself. That is, cities can dictate how transportation technology facilitates community goals rather than having to orient city policymaking to accommodate new transportation technologies. The following sections focus on how to do that. 


\subsection{GENERAL PRINCIPLES FOR MUNICPAL TRANSPORTATION REGULATIONS IN AN ERA OF NEW MOBILITY}

As described above, municipalities have struggled to respond to new transportation modes and mobility preferences, often reacting to the introduction of new technologies after they are already deployed and attempting to regulate each new mode individually. This approach to regulation requires cities to be reactionary and, because of the rapid pace of change, constantly developing new regulations. The result is piecemeal regulation that lacks flexibility to respond to new technologies. Further, because these regulations are focused on regulating individual technologies, they often fail to direct the use of the new mode in alignment with or to advance city goals and values for the use of public space.

\subsection{COMMUNITY GOALS AND MODAL PRIORITIES AS DRIVERS OF MOBILITY DECISIONS}

A foundational first step in designing flexible code that will allow cities to respond to changing transportation technologies in a manner that advances city priorities is to identify and articulate the city's goals and values for its public spaces-such as advancing equity, sustainability, community revitalization, and/or carbon reduction. Once adopted, regulators can use these goals to guide how new technologies are regulated and adopted. For example, goals around equity can guide how shared mobility is deployed in the city, and climate goals may support reduction in TNC VMT, or electrification of fleets.

We also recommend that such policies be applied to all modes of transport and not just to new modes; for example, regulations that govern scooter parking or speed ought to also be applied to vehicular parking and speed. That is, these new transportation technologies ought not to have higher standards placed on them than the existing predominant transportation modes simply because they are new. If anything, some of these new transportation modes ought to have preferential regulatory treatment when they represent space-efficient, low- or zero-carbon, and more equitable transportation-i.e., when they contribute more to achievement of city goals than existing modes.

These new technologies provide a unique opportunity for cities to revisit how their entire existing suite of transportation regulations and incentives are applied, and for what community outcomes.

In addition to these broader goals for public use, we recommend cities adopt targeted transportation goals that set priorities for transportation modes and street types or zones. These priorities can more specifically guide regulatory decisions, and if drafted with an eye towards advancing identified community goals, can support changes in the 
status quo. For example, Seattle's street types identify priority functions for streets, and direct the active conversion of the right-of-way to support those functions.

Finally, where citywide change is inappropriate or impracticable, the use of overlay zones can provide a means of adopting more proactive regulatory regimes. Overlay zones are limited geographic boundaries placed 'on top of' targeted areas of a community that provide additional regulatory requirements or relief. For instance, transit-oriented development overlay zones often remove parking minimums for new development due to their location in areas with frequent transit. We recommend extending this type of approach, but rather than linking overlay zones to existing infrastructure (e.g., transit), regulations should be tied to desired outcomes for specific areas-for instance, a city may wish to reduce automobile reliance and increase public transit and micromobility in dense urban cores.

The following sections delineate a range of policies and regulations that can help cities address the challenges when confronted with new transportation modes, help prepare them for the next unknown wave of mobility modes, and help modernize sets of regulations that have evolved over the last seventy years that prioritized and subsidized the single-occupancy vehicle as the main mode of transport for those able to own and operate such motorized vehicles.

\subsection{SPECIFIC RECOMMENDATIONS}

The following are eight key general principles, along with example model codes, that cities can use as they refine or adopt regulatory frameworks that address both new mobility modes and achieving broader municipal goals:

1. Identify city goals as drivers of decision making;

2. Create a clear modal hierarchy within the city's priorities for its transportation modes;

3. Require citywide compliance with city transportation policy;

4. Identify the purpose of the right-of-way as public space instead of the purview of automobiles;

5. Identify use of the specific functions of street types and zones;

6. Utilize overlay zones to provide flexibility to adopt different management priorities without systemic code changes;

7. Increase funding for non-automobile infrastructure and decrease funding for automobile infrastructure; and

8. Require data sharing as an essential part of new mobility infrastructure. 


\subsubsection{Identify city goals as drivers of decision making.}

Transportation decision making relates to all aspects of city life and function, and therefore it is critical that decisions about a city's transportation system not be made in isolation from overarching community goals, such as those concerning the urgent need to address climate change, affordable housing, and increasing social inequality. Cities can also be guided by other, high-level goals such as economic efficiency, community resiliency, maximizing community happiness, public health and safety, opportunity for all, attracting and retaining a future workforce, etc., as many of these goals are also connected to the same types of policies presented in the remainder of this report.

\section{Model Existing Sustainable Transportation Goals:}

"The transportation system increasingly uses active transportation, renewable energy, or electricity from renewable sources, achieves adopted carbon reduction targets, and reduces air pollution, water pollution, noise, and Portlanders' reliance on private vehicles." (City of Portland 2018) (Goal 9.D.)

"We are committed to climate action. We will transition our transportation sector to one that furthers our climate goals and builds replicable models for the rest of the world. New mobility services should use clean energy and expand humanpowered transportation." (Seattle Department of Transportation 2017)

\section{Model Existing Equitable Transportation Goals:}

"Mobility, whether shared, public, private, or automated, is a fundamental human need. Everyone needs a barrier-free transportation system and affordable transportation options that are understandable and accessible to all who want to use them. New mobility models should also promote clean transportation and roll back systemic racial and social injustices borne by the transportation system." (Seattle Department of Transportation 2017).

"The transportation system provides all [residents] options to move about the city and meet their daily needs by using a variety of safe, efficient, convenient, and affordable modes of transportation. Transportation investments are responsive to the distinct needs of each community." (City of Portland 2018) (Goal 9.E.)

\subsubsection{Create a clear modal hierarchy within the city's priorities for its transportation modes.}

At a citywide scale, it is imperative that there is clarity as to the priority of transportation modes and modal split in the community, and that these priorities inform other municipal decision making, such as development decisions. This prioritization can clarify the city's broader goals around environment, economy, equity, and health and safety and ensure that its transportation system decisions are being made in consistent ways with these larger goals. 


\section{Model Existing Modal Hierarchy:}

"Implement a prioritization of modes for people movement by making transportation system decisions according to the following ordered list:

1. Walking

2. Bicycling

3. Transit

4. Fleets of electric, fully automated, multiple passenger vehicles

5. Other shared vehicles

6 . Low or no occupancy vehicles, fossil-fueled non-transit vehicles" (City of Portland 2018) (Policy 9.6)

\subsubsection{Require citywide compliance with city transportation policy.}

To ensure that a city's identified goals and values for public spaces inform decision making around street design and allocation, cities should make clear that attaining sustainable transportation outcomes requires engagement by non-transportation departments such as economic development, parks, public health, social services, etc. Adopting code provisions requiring decision makers to comply with city policy in setting agency guidance, planning procedures, and outreach may be an additional approach to properly communicate that effective transportation systems meet multiple community goals.

\section{Model Existing Complete Streets Policy:}

"[City/Department/Etc.] will plan for, design and construct all new ... transportation improvement projects to provide appropriate accommodation for pedestrians, bicyclists, transit riders, and persons of all abilities, while promoting safe operation for all users ... and will incorporate Complete Streets principles into ... plans, manuals, rules, regulations and programs as appropriate." Seattle, Wash., Ordinance 122386 (2007), http://clerk.ci.seattle.wa.us/search/ordinances/122386. (The City of Seattle has a seventeen page "Complete Streets Checklist" "[f]or projects over \$500.000:"

https://www.seattle.gov/Documents/Departments/SDOT/UrbanDesignProgra m/2018_Standard\%20CS\%20Checklist\%20v3.pdf.)

\subsubsection{Identify the purpose of the right-of-way as public space instead of the purview of automobiles.}

Streets often represent the largest allocation of public space within a city and yet the vast majority of the street space tends to be allocated to the movement and storage of motorized vehicles in general, and the movement and storage of private automobiles in particular. This allocation has had a self-reinforcing impact over the last seventy years in which the allocation of street space for cars has made it easier to drive, creating demand for more space to move and store vehicles. Over the last 
twenty years, many communities have begun to rethink their streets and search for a more balanced allocation of space to car and non-car uses. Cities are evaluating a re-prioritization of space that favors more space-efficient and low-carbon transportation modes such as transit, walking, and biking, in addition to thinking of streets as places where community members enjoy mingling. The existence of TNCs, scooters and bicycle share systems, in addition to changing societal preferences toward less car-dependent neighborhoods and commercial areas provides an opportunity for cities to think of their streets as public spaces, and not just channels for vehicular throughput. There is now a window of opportunity to better align this more balanced approach toward street space allocation with the arrival and impact of new mobility modes, and this rebalancing ought to be a core principle for cities going forward.

\section{Model Existing "Streets as Public Spaces" Policies:}

"Streets, including sidewalks and planting strips, provide critical transportation and utility functions. ... streets are the most abundant type of public space, occupying nearly $[X X]$ percent of land area in the city. The following policies support community desire to expand the use of streets beyond their transportation functions. ..."

"Streets for transportation and public spaces: Integrate both placemaking and transportation functions when designing and managing streets by encouraging design, development, and operation of streets to enhance opportunities for them to serve as places for community interaction, environmental function, open space, tree canopy, recreation, and other community purposes."

"Encourage repurposing street segments that are not critical for transportation connectivity to other community purposes."

"Promote street and trail alignments and designs that respond to topography and natural features, when feasible, and protect streams, wildlife habitat, and native trees." (City of Portland 2018) (Policies 9.14 to 9.16.)

\subsubsection{Identify use of the specific functions of street types and zones.}

In some cases, there might be a desire to have regulations that govern specific subcity geographies to better integrate land use and transportation decisions to achieve a variety of positive outcomes not possible with a built environment organized around single-occupancy vehicles, such as creating transit-oriented-development areas. These prioritizations can then direct design and use of public spaces (e.g., prioritize public transit in downtown centers). While it may make sense for a city to have such policies universally applied, it may be politically more feasible in the short term to apply new land use and transportation policies to a more specific subgeography.

\section{Model Existing Policy for Specific Zone:}


Seattle has designated the area between the curb and the roadway as the "flex zone" and identified the priority function for the flex zone within each traditional land use zone (residential, commercial, and industrial). Further, within those priority functions it has identified the types of uses that will support those functions. This high-level planning provides guidance on how to prioritize uses of the right-of-way to meet community goals, with street space consideration given to the following uses:

- Mobility: sidewalks, bus or streetcar lanes, bike lanes, general purpose travel lanes, right or left turn only lanes

- Access for people: bus or rail stops, curb bulbs, passenger load zones, short term parking, taxi zones

- Access for commerce: commercial vehicle load zone, truck zone

- Activation: parklets and streateries, public art, street festivals

- Greening: Boulevards, street trees, planter boxes, rain gardens and bioswales

- Storage: bus layover, long-term parking, reserved spaces, construction

(City of Seattle 2019a). Seattle's prioritization of functions in the flex zone is depicted in Figure 1.

\section{Flex zone functions are prioritized based on surrounding land use}

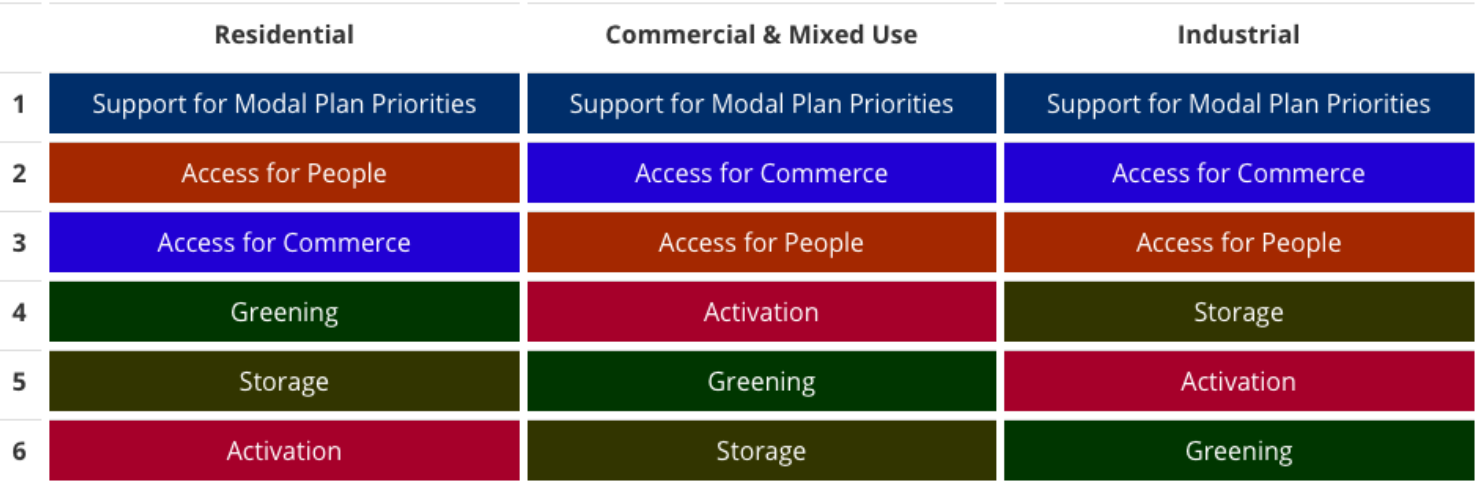

Figure 1: Seattle's Flex Zone matrix governing priority uses for the street by land use type. (City of Seattle 2019a).

\subsubsection{Utilize overlay zones to provide flexibility to adopt different management priorities without systemic code changes.}

Overlay zones, which sit over existing planning zones, have typically been used to establish specific development rules based on features within a base zone, for instance, wetlands or steep slopes. Another example is the use of zones to advance existing uses with the zone, such as transit zones where cities direct land use to promote the use of public transit (e.g., by reducing minimum parking requirements). 
Overlay zones also provide an opportunity for cities to direct the future use of an area to advance city goals around climate, equity, and sustainability. For instance, cities may identify areas based on population density to advance micromobility, pedestrian or bike access, and then direct use of the area in alignment with those priorities.

\subsubsection{Require Data Sharing as an Essential Part of New Mobility Infrastructure}

A common element of all shared mobility services is the availability of data, which offers cities the opportunity to gain valuable insights about usage, including reduced need for automobile parking, micromobility infrastructure needs, identifying appropriate TNC pickup/drop-off locations, monitoring of micromobility sidewalk use and parking behavior, use of new mobility to connect to transit, travel time implications, impacts on congestion, spatial and demographic equity attainment, safety considerations, and more.

The City of Seattle has characterized information as "the new infrastructure," and recognizes data infrastructure as "foundational to understanding, operating, and planning in a constantly changing transportation system" (Seattle Department of Transportation 2017). In the same vein, one of ten "Shared Mobility Principles for Livable Cities" is "We aim for public benefits via open data." Shared Mobility Principles for Livable Cities https://www.sharedmobilityprinciples.org/. While data sharing requirements are, strictly speaking, a form of modal regulation, the crucial role of mobility data in regulating the built environment in a manger that is responsive to actual usage and needs translates to the inclusion of data sharing among these general principles. Cities should not underestimate the importance of new mobility data, and should therefore ensure that access to data is included in policies, codes, contracts, pilot programs, etc.

Mandatory data sharing requirements for mobility providers (including TNCs and shared mobility at a minimum, and ideally all modes of travel as even newer private vehicles have sensors that communicate vehicle occupancy) would ideally exist at the state level. In the absence of statewide data sharing laws, cities should require data sharing as part of permitting right-of-way use.

\section{Model Existing Shared Mobility Data Sharing Provisions:}

"A. Permittees must provide the City or a City-identified third-party researcher or contractor access to data in accordance with the requirements specified in the City's mobility data specification published at https://github.com/CityofPortland/mobility-data-specification.

B. Permittees must maintain publicly available APIs in accordance with the requirements specified in the City's mobility data specification published at https://github.com/CityofPortland/mobility-dataspecification/tree/dev/provider\#realtime-data. 
C. Permittees must provide the City with anonymized data regarding Chargers and Users at monthly intervals.

D. Permittees must provide the City with anonymized data regarding Users and non-Users / public reports at monthly intervals, including at a minimum: Unique reporter ID; Address, intersection, or coordinates (required field); Scooter ID (required field); Permit ID (optional field); Issue type (Required field) (Response options should include, at minimum: Parking, maintenance, other); Report Description; Form submission timestamp (required field).

E. The Permittee shall notify the City and all required Users of a known data security breach in the same manner as provided in ORS 646A.600 to ORS 646A.628.

F. If the City receives a request for any confidential information pursuant to a Public Record request pursuant to ORS Chapter 192, or any other applicable law or is sued in order to obtain the disclosure of such information, the City shall promptly notify Permittee upon receipt of such request or lawsuit so as to afford Permittee the opportunity to take steps to prevent disclosure. In the event the City is ordered by a court of competent jurisdiction that a portion or all of the confidential information is not required to be kept confidential or does not constitute trade secrets or confidential information exempt from disclosure, or disclosure is otherwise required by law, the City shall provide Permittee prompt notice before complying with the court order or law, so that Permittee may take appropriate actions, including seeking an injunction, appeal and stay of the court order or otherwise challenge the law. Further details may be enumerated in the data sharing agreement.

G. The Permittee agrees that the PBOT may use a third-party researcher or contractor to evaluate the Shared Scooter Pilot. Permittee shall share all data with the third-party researcher or contractor necessary for purposes of the evaluating the goals, objectives, and requirements in this permit.

$\mathrm{H}$. The Permittee agrees to participate in the evaluation of the Pilot Period, including but not limited to distributing City surveys to Shared Scooter Users, employees, and contractors hired to deploy, re-charge or swap batteries, or repair Shared Scooters;

I. If disclosure of any data collected by the City is required by law, the City will provide Permittees notice prior to any disclosure of such data so that they may take appropriate legal action.

J. Upon request, the Permittees shall provide data identified by the Director to verify compliance with requirements pursuant to this Rule. 
K. A failure to comply with any provision of this Section is a Class B violation subject to the penalties provided in Section 11, Enforcement Penalty Schedule, and may subject the permit to suspension or revocation. Penalties will be applied per violation and per day the Permittee is in violation of City Code and this Rule." (Portland Bureau of Transportation. 2019a (Section 6).)

The sections that follow include model policies and model code provisions that build on the general principles discussed in this section. These policies and codes work best if cities have identified goals and prioritized transportation modes, and if cities require that transportation decisions citywide (i.e., across all departments, bureaus, etc.) are in accordance with city goals and priorities. Additionally, many of the policies and codes that follow depend on city access to reliable data on new mobility usage of public spaces, which allows cities to alter urban form and regulation in accordance with usage patterns. 


\subsection{REGULATION OF THE BUILT ENVIRONMENT}

Even though many cities seem to focus on how to directly regulate (or not) the private companies providing new mobility options, updating approaches to regulating the built environment is potentially more important than regulating modes of transport themselves. In particular, the regulation of the public right-of-way, including the street, the curb, and the sidewalk, are often in desperate need of updating after seventy years of local regulation primarily focused on the movement and storage of private automobiles.

\subsection{MANAGEMENT OF THE CURB FOR MORE THAN ON-STREET PARKING}

Curb space is a critical component of the city's right-of-way, providing the connection between the street and the community, with curb management characterized as the "nexus of transportation, land use, and economic development" (Institute of Transportation Engineers 2018). How cities manage curb space significantly influences who can access public spaces, and in turn how public spaces are used by the community (Chase 2018) and has the potential to significantly contribute to the sustainability and livability of cities. Until recently, curb management was largely ignored by cities, with the curb thought of as the province of private vehicle parking (Institute of Transportation Engineers 2018). However, the adoption of new transportation modes (e.g., TNCs and micromobility) has increasingly demanded the availability of curb space, creating and highlighting the need to assess how cities manage the curb. These new challenges present an opportunity for cities to consciously rethink the use of curb space, prioritize uses and users, and direct changes in how communities utilize this broadly-distributed element of the public domain. Curb management policies that have successfully responded to changing demands and re-prioritized curb spaces away from private vehicle parking have identified policy goals around curb use and adopted regulations with sufficient flexibility to address on-the-ground demands. Cities need flexibility to manage the curb in harmony with clear and enforceable policies to guide management.

With respect to curb management specifically, the City of Portland provides a good example of recognizing the curb as more than an automobile parking zone. Portland's Comprehensive Plan "recognize[s] that the Curb Zone is a public space, a physical and spatial asset that has value and cost" (City of Portland 2018 (Policy 9.50)). The plan directs agencies to "evaluate whether, when, and where parking is the highest and best use of this public space in support of broad City policy goals and local land use context [and] [e]stablish thresholds to utilize parking management and pricing tools in areas with high parking demand to ensure adequate on-street parking supply during peak periods" (City of Portland 2018 (Policy 9.56)). Finally, the Comprehensive Plan directs the use of flexible design of rights-of-way so that they can accommodate evolving uses: "reflect the 
pattern area and other relevant physical, community, and environmental contexts and local needs" (City of Portland 2018 (Policy 8.47)).

Portland's plan also adopts an on-street parking management policy to "reduce parking demand and manage supply to improve pedestrian, bicycle and transit mode share, neighborhood livability, safety, business district vitality, vehicle miles traveled, and air quality." This includes directing the reduction of new parking demand and private vehicle ownership, "encourag[ing] the shared use of parking and vehicles," and implementation of parking fee structures that appropriately reflect the "cost of providing parking and balance demand and supply" (City of Portland 2018 (Policies 9.55 \& 9.60)). Finally, the Comprehensive Plan also provides a prioritization of curb use for parking based on location in the city. For example, the Comprehensive Plan provides that parking in the Central City should be prioritized for short term parking, carpool vehicles and lastly, long term parking.

Recent Uber-commissioned studies in San Francisco (Fehr \& Peers 2018) and Cincinnati (Fehr \& Peers 2019a) have used data to propose redesigned curb spaces that would better meet demand and increase curb productivity. Both studies focused on specific types of use areas. The San Francisco study focused on four types of areas: a transportation hub; a commercial corridor, a high-density office neighborhood; a financial district; and a bike corridor. For each of these areas, the study looked at existing curb design, passenger loading impact, curb productivity, and demand. The study then provided options to increase curb productivity in each area, focusing on passenger pickup and drop-off.

As illustrated by these Uber-commissioned studies, TNCs (as would be expected) have fine-grained data on usage. This is of course also the case regarding micromobility providers, i.e., they too have fine-grained data on the whereabouts and usage of their bikes, scooters, etc. Such data offers the possibility of a treasure trove of useful information about new mobility usage (and misusage) of the public realm, and municipal access to it offers a key means of determining how the built environment can best mesh with new mobility so as to achieve municipal goals. Because such data is potentially so valuable to cities, model data sharing provisions appear in the "general principles" section above.

The use of data to understand curb use has allowed cities to redesign curb space to meet actual demand, resolve problems around congestion and safety, and implement land use policy choices. Changing transportation mode preferences have highlighted the importance of understanding curb demand. For instance, the rapid increase in ecommerce has shifted delivery points from industrial/commercial areas to residential areas typically without loading zones (Pyzyk 2018). Similarly, the rise of TNC use has increased demand for passenger pickup/drop-off, stressing typically scarce short-term curb access. Additionally, adoption of both docked and dockless micromobility has resulted in increased numbers of bikes and scooters occupying the sidewalk and curb zone. 


\subsubsection{Three Approaches to Modifying Curb Use: Relocation, Flexibility, and Conversion}

Responding to this changing demand, cities are reallocating curb space for vehicle and public transportation access. A recent study identified three primary means of modifying curb use to address demand (Fehr \& Peers 2019a):

1. Relocation;

2. flexibility; and

3. conversion.

\subsubsection{Relocation}

Relocation involves maintaining existing uses at current levels but redesigning the place of use within the block to address curb congestion. This strategy will often be the most politically palatable as it involves less disruption to existing uses; however, it is the least likely to address curb congestion or result in changes to community use patterns. A simple example is moving the location of commercial loading to the end of the block (providing easier access for delivery vehicles) and motorcycle parking to the middle of the block.

To implement this strategy, city code must authorize the change in curb zones designations, such as the establishment of meter zones, commercial loading/unloading zones, or time zones. For example, the Portland City Code authorizes the City Traffic Engineer to designate regulated parking zones. The city traffic engineer may consider, among other factors: the land use of the area, traffic volume, parking volume, street layout and whether parking for the general public is needed. All decisions must be made to benefit the public welfare. Portland, Or. Code $\S 16.20 .203$ (2019). Another example in Portland's City Code is the authorization to establish truck loading zones in order "to prevent double parking and other illegal parking by designating a supply of parking spaces dedicated to the delivery of merchandise by trucks to commercial properties." Portland, Or. Code $\S 16.20 .220$ (2019). San Francisco's code, in contrast, requires a public hearing prior to the modification of any parking zone including establishing a no parking zone. San Francisco, Cal. Planning Code $\S 150$ (2019). The designation of authority to modify existing curb zones will impact the ability of a city's transportation agency to be responsive to changing demands.

\subsubsection{Flexibility}

Flexibility involves a dynamic approach to curb allocation that is responsive to demand. This approach is particularly useful where there is a "mix of land uses with overlapping demands of curb space" (Fehr \& Peers 2018). Both technology and flexible regulations play important parts in applying this approach. Code can incorporate technology both in assessing demand and adjusting curb uses based on that demand. Examples of flexible code provisions that allow for responsive curb management may include 
authorizing modifications based on certain triggers, allowing for dynamic curb zones, and providing discretion to agencies to make changes within certain parameters.

Several cities have used improved data collection to implement demand-based parking pricing, allowing cities to more accurately price their curb spaces based on actual demand and desired type of curb use. In 2011, San Francisco began a pilot program known as SFpark, installing sensors that detect occupancy of a parking spaces (Descant 2018). Using data collected on occupancy and duration, the city adjusted parking rates up or down in order to meet occupancy and turnover targets. The pilot was subsequently formally adopted as part of the city code. Under the code provisions, SFMTA authorizes the transportation authority to set rates between $\$ 0.50$ and $\$ 8.00$ hour, adjustable every twenty-eight days based on occupancy targets set in the code: $80 \%$ occupancy requires a rate increase of $\$ 0.25$ and below $60 \%$ occupancy requires a $\$ 0.25$ reduction in the rate. A similar scheme is set for event parking: areas are designated by the SFMTA but discretion is given to the Director of Transportation to set an initial rate which is then mandated to adjust based on occupancy levels (above $90 \%$ requires a $\$ 0.50$ increase and below $65 \%$ a corresponding decrease). Information on rates in particular areas is available to drivers through mobile applications.

Los Angeles's LA Express Park similarly uses sensors to determine occupancy and turnover and adjusts parking rates to drive use towards desired occupancy targets. The Municipal Code sets initial parking rates for "Demand-Based Parking Meter" areas, then authorizes the Los Angeles Department of Transportation (LADOT) to increase or decrease rates. L.A., Cal. Municipal Code $\S$ 88.00.2. (2019). LADOT's discretion is capped at a 100 percent increase, and may not decrease rates below $\$ 0.50$ per hour for the first four hours and $\$ 2.00$ for up to ten hours. The Municipal Code sets the desired occupancy at 70 to 90 percent. LADOT is required to report to the City Council once a year on parking rates.

The City of Los Angeles' Modified Parking Requirement provides a different example of flexible curb management. The ordinance gives LADOT the discretion to select between seven management options in setting parking minimums. These include reducing parking or eliminating parking requirements. While most relate to off-street parking, one management option includes meeting parking requirements through the purchase of on street parking spaces (either for all hours/days or for specific times). L.A., Cal. Municipal Code § 13.15. (2019).

Finally, the District of Columbia has adopted a pilot program authorizing the temporary conversion of curb space from private vehicle parking to passenger pickup and drop-off in the "Golden Triangle," where double-parked TNCs and high numbers of pedestrians had created a safety risk. Existing authority was leveraged to implement the program, with existing authority including a prohibition of parking in restricted zones and discretion to impose additional parking restrictions around restaurants and entertainment facilities. D.C. Code § 50-2662 (2019). 


\subsubsection{Conversion}

Conversion involves a permanent change in curb use along an entire block. Existing provisions governing relocation often provide conversion authority. For example, the San Francisco Municipal Code provides the San Francisco City Traffic Engineer discretion to convert existing parking spaces to "white zones" designated for passenger pickup/drop-off by TNCs and designated private bus systems. San Francisco, Cal. Transportation Code $\S 201$ (2019).

A more dramatic type of conversion is the removal of parking and installation of a transit lane. Cities generally authorize the restriction of parking on a block face and provide for the designation of transit lanes. For example, the City of Portland authorizes the designation of transit-only lanes and generally prohibits stopping or parking in bus zones with certain exceptions, which include use by taxi cabs outside of rush hour times and limited to a period of fifteen minutes. Portland, Or. Code $\S \S 16.10 .200$ B. \& K. (2019). San Francisco similarly permits the City Traffic Engineer to designate of transitonly lanes with approval from the Municipal Transit Agency board.

In implementing curb management strategies, cities have drawn from a diverse range of regulatory tools ranging from comprehensive plans and transportation plans to codes and administrative rules. Each of these regulatory tools provide different opportunities to direct curb use.

\subsubsection{Rethinking priority uses of the curb}

The identification of priority uses for curb space provides an opportunity for cities to direct future curb management beyond existing uses and drive changes in use patterns.

The City of Seattle's "Flex Zone" provides an example of this approach. As part of its comprehensive plan, the City identified priority uses for the curb space-reimagined and renamed as the "Flex Zone" (City of Seattle 2019a). Uses are prioritized by the desired function for the curb space:

- "mobility" ("Moves people and goods"),

- "access for people" ("People arrive at their destination, or transfer between different ways of getting around"),

- "access for commerce" ("Goods and services reaching their customers or markets"),

- "activation" ("Offers vibrant social spaces"),

- "greening" ("Enhances aesthetics and environment health"), and

- "storage" ("for vehicle or equipment"). 
The function prioritized in each zone informs how Seattle manages the curb space within that zone. For example, where mobility is prioritized, uses may include bike lanes, sidewalks, and travel lanes; where activation is prioritized, uses may include food carts, public art, and parklets; greening zones would include uses such as bio-swales, rain gardens, street trees or planter boxes. The Comprehensive Plan prioritizes these functions based on the zoning of the surrounding area (Residential, Commercial \& Mixed Use and Industrial). For example, in residential zones, mobility is prioritized, followed by access for people, then access for commerce, greening, storage, and activation.

The City of Seattle's Right-of-Way Improvements Manual provides another example of policy-level planning directing curb management (City of Seattle 2019b). Within the manual, the City has overlaid typical functional street designations (e.g., arterial, residential access, alley) with street types "based on the adjacent land uses and envisioned character of the streets." These street types are intended to direct the management of right-of-way, curb, and pedestrian zone to support the identified use of the area. For example, the "neighborhood corridor" street type is designed to "balance[] with the safety and access needs of those who live in the adjacent neighborhoods ... [to] encourage slower traffic speeds and minimize the number of travel lanes in order to enhance pedestrian and bicycle safety." With this in mind, streets are designed with a wide pedestrian zone, bike lanes, greening (street trees), and limited public transit. Curb space is prioritized for transit and separated bike lane, with limited on-street parking. In another example, Urban Village Neighborhood streets "serve a variety of land uses, with more emphasis on residential uses and curbside uses that provide amenity and activation." Curb use in this area focuses on loading and parking zones.

Portland's Comprehensive Plan provides another example of rethinking priorities for curb use at a policy level. Goal 9.6 of the Plan identifies a hierarchy of transportation modes and directs the prioritization of these modes when making decisions regarding the transportation system: pedestrians; bicycles; public transit; "fleets of electric, fully automated, multiple passenger vehicles"; other shared vehicles; "low or no occupancy vehicles, fossil-fueled non-transit vehicles" (City of Portland 2018). While not specific to curb use, this transportation priority would theoretically direct curb management.

\subsubsection{Specific Recommendations}

The following are recommendations regarding management of the curb for more than parking:

1. Designate 'curb zones' or 'curb lanes';

2. Provide clear guidance on city goals and values for curb use;

3. Require compliance with established goals and priorities in allocating curb space;

4. Provide authority to regulators to repurpose right-of-way; 
5. Provide flexibility in designating use of public spaces;

6. Authorize agency to set time, place and manner of curb use;

7. Authorize agency to set fees for curb use;

8. Direct collection of parking fees to non-automobile infrastructure;

9. Include non-transport uses as acceptable uses in curb zones;

10. Require repurposing of on-street parking for micromobility; and

11. Authorize the use of demand-based parking rates.

\subsubsection{Provide clear guidance on city goals and values for curb use.}

Cities should clearly identify priority goals and uses for the right-of-way and expressly permit and prioritize reallocation to advance those uses. At a citywide scale, cities need to articulate a hierarchy of transportation priorities and then support that hierarchy through both transportation and land use decisions (as well as supporting public health, social equity, happiness, and economic development considerations). This prioritization clarifies the city's broader goals in terms of which transportation modes it wants to support and grow, at which point the city can streamline the conversion of curb or traffic lanes when clear opportunities emerge, for example when parking utilization decreases due to increased TNC or micromobility use.

\section{Model Existing Policy:}

Make "transportation system decisions according to the following ordered list: walking, bicycle, transit, fleets of electric, fully automated, multiple passenger vehicles; other shared vehicles; low or no occupancy vehicles, fossil-fueled non-transit vehicles." (City of Portland 2018 (Policy 9.6)).

\subsubsection{Provide authority to regulators to repurpose right-of-way.}

Reallocating underutilized curbside parking or simply repurposing such public space to meet greater social demand and goals represents one clear area of opportunity for cities to reclaim this public space to serve the greater public good.

\section{Model Existing Code Provision:}

The designated decision maker may "[e]stablish, remove, or alter traffic controls, including but not limited to ... traffic lanes ... bicycle lanes ... . parking areas" and may [d]esignate transit lanes and street locations where certain transit vehicles may proceed in a manner prohibited to other traffic" Portland, Or. Code $\S \S 16.10 .200 . B$ \& K. (2019). 


\subsubsection{Authorize agency to set time, place and manner of curb use.}

Ensure that it's clearly spelled out which governmental arm of the city has authority over the curb, along with the particular elements of that authority over the curb.

\section{Model Existing Code Provision:}

The [Agency] may "determine the location of and establish passenger loading zones and in each case to fix the hours during which such zones shall be maintained open for the purpose for which the same are intended." Seattle, Wa. Municipal Code § 11.16.280(C) (2019).

\subsubsection{Authorize agency to set fees for curb use.}

Given the inherent value of the curb for various uses, empower the city to establish and collect fees for curb usage where appropriate.

\section{Model Existing Code Provision:}

"The Transportation Director and/or City Council may establish fees and charges [for street use].” Portland, Or. Code § 16.10.500 (2019).

\subsubsection{Include non-transport uses as acceptable uses in curb zones.}

Curb zones should be 'opened up' to allow such activities as parklets, microparks, and community art. For example, under Seattle's "Flex Zone" model (discussed above), curb zones can be used as (among other things) a "greening zone" (for street trees, planter boxes, rain gardens and bio-swales) or as an "activation zone" (for community use such as parklets and streateries, public art, and street festivals). Regulations should authorize parklets as minor encroachments into the right-of-way, define parklets, require that parklets to be publicly accessible, and clarify locations and entities that may hold permits.

\section{Model Existing Code Provision:}

"[T]he City [Division/Department/etc.] . . may approve Parklets, Benches and/or Planters in the public right-of-way (excluding Sidewalks ...

'Parklet' means a platform or similar level surface extending into the public right of way with amenities such as but not limited to tables and/or chairs (including Benches), Bike Parking, and umbrellas, designated as public space, located in or on the public right-of-way or resting on, or projecting into, the sidewalk and parking area, which are not physically or structurally attached to a building, retaining wall or fence. ... All Parklets shall be subject to the following additional standards and requirements: 
a. Parklets must remain publicly accessible and must include signage posted on site to this effect;

b. Parklet construction materials must be of high quality, durable, and suitable for public use;

c. A visible edge to the Parklet is required, which may consist of Planters, railing, or cabling. The edges should be visually permeable;

d. The Permittee shall regularly inspect and clean the Parklet and that portion of the public sidewalk adjacent to the Parklet;

e. Access panels must be included in order to maintain the gutter and area underneath the Parklet and the design must allow for drainage along the gutter to pass underneath the Parklet;

f. Safe hit posts and wheel stops, or approved equivalents, may be required. If Bike Parking is provided, the bike racks can be at street grade." Berkley, Ca., Municipal Code $\$ 14.48 .190$ (2019).

\subsection{OFF-STREET PARKING MINIMUMS}

Transportation and parking are interrelated (Davidson 2002). Throughout the United States, cities have been planned around a cultural reliance on the automobile and the necessary accommodations to keep the car at the top of the transportation food chain (Davidson 2002). For decades, municipalities have applied minimum off-street parking requirements to development and redevelopment projects of every conceivable size, type, and context. The accommodations provided to auto travel and storage in the form of parking can have a substantial effect on cities, often affecting the ability of a municipality to provide affordable housing, effective economic development, and mixed transportation choices. Minimum parking standards can require development projects to dedicate as much as or more land area to parking than the land area needed for buildings/improvements (Davidson 2002). Minimum parking requirements have resulted in an oversupply parking in some areas. Given the impact minimum off-street parking requirements can have on a community, many municipalities have abolished parking minimums either citywide or for particular areas (Shoup 2015).

\subsubsection{Citywide Parking Reform}

Buffalo, New York was the first major city in the U.S. to reform its zoning code to completely remove minimum parking requirements citywide. Buffalo's Unified Development Ordinance (UDO), combines zoning, subdivision, and public realm standards into a single regulatory document that applies to all land, structures, and uses within the corporate boundaries of the City (Buffalo, N.Y., Unified Development Ordinance (2016), https://ecode360.com/attachment/BU1237/Buffalo_UDO.pdf). In removing minimum parking requirements, Buffalo relies on a market-based approach to address the city's parking needs, essentially granting property owners the option to provide off-street parking facilities based on need.

Hartford, Connecticut was the second major city in the U.S. to remove minimum offstreet parking requirements citywide in order increase walkability and spur development 
(Hartford, Conn., Zoning Regulations $\S 7$ (2019), http://hartford.gov/images/DDS_Files/Plan_Zoning/Zoning_Regs/ZoningRegulations(4)0 3252019SB.pdf). Hartford's revised zoning code does not require developers to include parking in new construction, and uses a market-based approach to parking while also imposing parking maximums. The city initially removed mandatory minimum off-street parking from its downtown core in 2015. As a result of removing mandatory minimums downtown, Hartford experienced the benefit of more efficient redevelopment and renovation. City officials and Hartford residents are expecting to see a citywide benefit in the form of a reduction in housing costs, traffic and pollution (water and urban heat island) because of the revised code. Hartford provides an example of a city trying removal of parking minimums on a limited basis, then expanding the removal of minimums based on initial success.

San Francisco is the third major U.S. city to eliminate minimum off-street parking requirements citywide (S.F., Cal., Planning Code $\S 151$ (2019)), followed by Minneapolis, which recently approved the elimination of parking minimums with an effective date of January 1, 2020 (City of Minneapolis 2019).

\subsubsection{Non-Citywide Parking Reform}

While a handful of cities have removed minimum off-street parking requirements citywide, numerous municipalities have removed minimum off-street parking requirements from specific areas within their jurisdictions, generally recognizing the same issues posed by parking minimums that have been cited by cities eliminating minimums on a broader scale. A Strong Towns.org map that tracks the progress of removing parking has identified ninety-nine (and counting) municipalities in the U.S. that have removed minimum off-street parking requirements in at least one area of their city (Strong Towns 2018). A few examples of non-citywide parking reform follow.

The City of Eugene has designated multiple areas as motor vehicle parking-exempt areas. Land uses within parking-exempt areas are not required to abide by parking minimums that apply outside of such areas (Eugene, Or., Code $\$$ 9.6410(4) (2019)). Additionally, the City of Eugene allows for adjustments to parking minimums outside of parking-exempt areas based on compliance with applicable criteria. Seattle exempts its downtown zones from off-street parking requirements except in limited circumstances, and provides for parking reductions for multifamily, industrial and new or expanding offices or manufacturing located in frequent use transit service areas (Seattle, Wash., Municipal Code $\S 23.54 .020$ (2019)). Similarly, the City of San Diego eliminated minimum parking requirements for new housing developments in "transit priority areas," an effort aimed at making housing more affordable and at combatting climate change by encouraging public transportation (San Diego, Cal., Code $§ 142.0528$ (2019)). "Transit priority areas" are within one half-mile of a current or planned transit stop, with a planned transit stop being one that is funded and scheduled to be completed within five years. 


\subsubsection{Specific Recommendations}

We recommend that cities provide regulatory caps on new off-street parking and authorize the removal of existing off-street parking minimums. Where a city proposes to maintain parking minimums, parking maximums are recommended, along with allowance for pooled parking and other public uses. Finally, regulations should propose inclusion of non-automobile parking requirements as well as greening requirements. Specific recommendations are as follows:

1. Remove automobile parking minimums;

2. Establish parking maximums for new development;

3. Establish parking maximums for existing development;

4. If minimum parking requirements remain, add flexibility by allowing for the elimination or reduction of parking minimums where other services are provided; start with the presumption that elimination of parking is a net positive, and adjust;

5. Decouple off-street parking rates in rental properties;

6. Permit the conversion of existing off-street parking spaces to other uses;

7. Maintain parking minimums but incorporate maximums as set above;

8. Allow for the use of pooled parking to meet any minimum;

9. Allow for removal of parking when unused;

10. Create parking zone maximums;

11. Mandate minimum micromobility parking; and

12. Provide incentives for existing development to meet micromobility parking requirements applicable to new development.

\subsubsection{Remove automobile parking minimums.}

The most meaningful action a local government can take related to vehicular parking is to completely eliminate minimum parking requirements; there is little justification for their continued existence. As discussed above, cities wishing to take a more measured approach may elect to eliminate parking minimums for designated areas (instead of citywide), and then expanding coverage to more of the city in phases.

\section{Model Existing Policies:}


"Eliminate the requirement for off-street parking minimums throughout the city, acknowledging that demand for parking will still result in new supply being built, and re-evaluate established parking maximums to better align with City goals." (City of Minneapolis 2019, 119).

"There are no provisions that establish a minimum number of off-street parking spaces for development. However, certain [larger] development proposals are required to complete a transportation demand management plan ...." Buffalo, N.Y., § 8.3.1A. Unified Development Ordinance (2016), https://ecode360.com/attachment/BU1237/Buffalo_UDO.pdf.

\subsubsection{Establish parking maximums for new development.}

Cities that are unable or unwilling to eliminate parking minimums should at least establish parking maximums for new development. As indicated in the City of Minneapolis provision in the previous section, cities eliminating parking minimums can also establish parking maximums.

\section{Model Existing Code Provisions:}

Maximums are generally tailored to particular uses:

\begin{tabular}{|l|l|}
\hline "One-Unit Dwelling" & $\begin{array}{l}\text { "Maximum 4 spaces per } \\
\text { zoning lot" }\end{array}$ \\
\hline $\begin{array}{l}\text { "2- \& 3- Unit Dwelling, } \\
\text { Multi-Unit Dwelling, } \\
\text { Efficiency/Micro Unit" }\end{array}$ & "Maximum 2 spaces per unit" \\
\hline $\begin{array}{l}\text { "Bed \& Breakfast, Hotel/ } \\
\text { Apartment Hotel" }\end{array}$ & $\begin{array}{l}\text { Maximum 1.5 spaces per } \\
\text { guest rooms } \\
\text { "Eating Places" }\end{array}$ \\
$\begin{array}{l}\text { "Maximum 3 spaces for every } \\
\text { capacity" }\end{array}$ \\
\hline
\end{tabular}

Hartford, Conn., Zoning Regulations § 7 (2019), http://hartford.gov/images/DDS_Files/Plan_Zoning/Zoning_Regs/ZoningRegul ations(4)03252019SB.pdf (From Figure 7.2-A on page 232).

\subsubsection{If minimum parking requirements remain, add flexibility by allowing for the elimination or reduction of parking minimums where other services are provided; start with the presumption that elimination of parking is a net positive, and adjust.}

Cities with parking minimums can soften the impact of these minimums by allowing reductions in minimums in exchange for desired alternatives to automobile parking, such as micromobility, motorcycle, or carshare parking; trees; bikeshare stations/kiosks, and/or transit plazas. 


\section{Model Existing/Suggested Code Provisions:}

The minimum number of required parking spaces for both existing and new developments may be reduced or eliminated as follows:

For every non-required five designated micromobility parking spaces, required vehicle parking spaces may be reduced one space. Micromobility parking spaces must include a fixed structure, meeting city design standards, for securing micromobility devices.

"Motorcycle parking may substitute for up to 5 spaces or 5 percent of required automobile parking, whichever is less. For every 4 motorcycle parking spaces provided, the automobile parking requirement is reduced by one space. Each motorcycle space must be at least 4 feet wide and 8 feet deep. Existing parking may be converted to take advantage of this provision."

"Minimum parking may be reduced by one parking space for each tree 12 inches in diameter and larger that is preserved. A maximum of 2 parking spaces or 10 percent of the total required may be reduced, whichever is greater. However, required parking may not be reduced below 4 parking spaces under this provision."

$50 \%$ of the required parking may be reduced where the space otherwise allocated to parking is utilized as a community green space or for green infrastructure.

"For every car-sharing parking space that is provided, the motor vehicle parking requirement is reduced by 2 spaces, up to a maximum of 25 percent of the required parking spaces ... car-sharing parking spaces must be shown on the building plans; and ... [a] copy of the car-sharing agreement between the property owner and the carsharing company must be submitted with the building permit."

"City of Portland bike-sharing stations may substitute for required parking if all of the following are met:

(1) A City of Portland bike-sharing station providing 15 docks and 10 shared bicycles reduces the motor vehicle parking requirement by 3 spaces. The provision of each addition of 4 docks and 2 shared bicycles reduces the motor vehicle parking requirement by an additional space, up to a maximum of 25 percent of the required parking spaces;

(2) The bike-sharing station must be adjacent to, and visible from the street, and must be publicly accessible; 
(3) The bike-sharing station must be shown on the building plans; and

(4) A copy of the signed agreement between the property owner and the Portland Bureau of Transportation must be submitted before the building permit is approved."

"A transit-supportive plaza may substitute for up to 10 percent of the required parking on sites where at least 20 parking spaces are required, and where at least one street lot line abuts a transit street. Existing parking areas may be converted to take advantage of these provisions. The plaza must meet the following regulations. Adjustments to the regulations of this Subparagraph are prohibited:

(1)The plaza must be adjacent to and visible from the transit street. If there is a bus stop along the site's frontage, the plaza must be adjacent to the bus stop;

(2) The plaza must be at least 300 square feet in area and be shaped so that a 10 foot $\times 10$ foot square will fit entirely in the plaza;

(3) The plaza must be open to the public. The owner must record a public access easement that allows public access to the plaza; and

(4) The plaza must include all of the following elements: A bench or other sitting area with at least 5 linear feet of seating; A shelter or other weather protection that covers at least 20 square feet. If the plaza is adjacent to the bus stop, TriMet must approve the shelter; and Landscaping." Portland, Or., Code § 33.266.110.D. (2019).

\subsubsection{Decouple off-street parking rates in rental properties.}

Where off-street parking is provided as an amenity, parking costs should be assessed separately and be elective for renters. Decoupling parking costs assists in allocating costs of private vehicle ownership to individuals electing to own vehicles and incents non-vehicle ownership through cost savings. Cities could also provide that parking spaces may be rented to non-residents when the number of parking spaces exceeds the demand by residents.

\section{Model Existing Code Provisions:}

"Off-street parking accessory to rented or leased multifamily dwelling units shall not be included in any dwelling unit rental agreement and shall be subject to a rental agreement or addendum or in a separate rental agreement."

"Unless commercial uses are listed as exempt ... off-street parking accessory to rented or leased commercial use spaces in structures that contain 4,000 square feet or more of gross floor area shall not be included in any new rental or lease agreement and shall be subject to a separate rental or lease agreement. ... Exempt uses include: (a) Lodging 
uses; (b) Sales and services, automotive; (c) Sales and services, heavy; and Sales and services, marine." Seattle, Wash. Municipal Code $\S$ 23.42.070 (2019).

\subsubsection{Maintain parking minimums but incorporate maximums as set above.}

Maximum parking requirements should be set at the lowest possible level and should be flexible based on the goals of the area, proximity to transit, and nonmotorized vehicle transportation.

\section{Model Existing Code Provisions:}

"Sites that are located in close proximity to transit, have good street connectivity, and good pedestrian facilities may need little or no off-street parking. Parking requirements should be balanced with an active pedestrian network to minimize pedestrian, bicycle and vehicle conflicts as much as possible. Transit-supportive plazas and bicycle parking may be substituted for some required parking on a site to encourage transit use and bicycling by employees and visitors to the site. The required parking numbers correspond to broad use categories, not specific uses, in response to this long term emphasis. Provision of carpool parking, and locating it close to the building entrance, will encourage carpool use."

"Limiting the number of spaces allowed promotes efficient use of land, enhances urban form, encourages use of alternative modes of transportation, provides for better pedestrian movement, and protects air and water quality. The maximum ratios in this section vary with the use the parking is accessory to and with the location of the use. These maximums will accommodate most auto trips to a site based on typical peak parking demand for each use. Areas that are zoned for more intense development or are easily reached by alternative modes of transportation have lower maximums than areas where less intense development is anticipated or where transit service is less frequent. In particular, higher maximums are appropriate in areas that are more than a 1/4 mile walk from a frequently served bus stop or more than a $1 / 2$ mile walk from a frequently served Transit Station." Portland, Or., Code §§ 33.266.110.A. \& 33.266.115.A. (2019).

\subsubsection{Allow for the use of pooled parking to meet any minimum.}

This provides additional flexibility to use existing parking spaces that may go unused by allowing for the use of land that would otherwise be dedicated to private vehicle parking.

Model Existing Code Provision: 
"Off-Site Shared Parking. Shared parking is intended to provide an opportunity for multiple uses to use parking facilities on separate properties more efficiently. Shared parking shall be permitted in all nonresidential districts ... subject to [various requirements] ... .

On-Site Shared Parking. Facilities may be shared if multiple uses cooperatively establish and operate parking facilities and if these uses generate parking demands primarily during hours when the remaining uses are not in operation. (For example, if one use operates during evenings or weekdays only.) The applicant shall have the burden of proof for a reduction in the total number of required parking spaces, and documentation shall be submitted substantiating the reasons for this requested parking reduction. Allow for removal of parking when unused." Santa Monica, Cal., Municipal Code §§ 9.28.180.D. \& E. (2019).

\subsubsection{Mandate minimum micromobility parking.}

Cities should incorporate minimum parking requirements for micromobility into land use requirements. Requiring minimum parking for micromobility generally (versus phrasing minimum requirements in terms of particular modes (such as bicycles or scooters) provides increased flexibility for the use of new technologies in cities. The example provision provides regulatory flexibility. See appendix for an example of minimum bicycle parking provisions that could be broadened to cover micromobility more generally/not limited to bicycles.

\section{Model Existing Code Provision:}

"[Micromobility] parking is required for most use categories to encourage the use of [micromobility] by providing safe and convenient places to park [micromobility devices]. These regulations ensure adequate short and long-term [micromobility] parking based on the demand generated by the different use categories and on the level of security necessary to encourage the use of [micromobility] for short and long stays. These regulations will help meet the City's goal that 10 percent of all trips be made by [micromobility]." Portland, Or., Code § 33.266.200 (2019). 


\subsection{REGULATION OF MODES}

Whereas the previous section addressed regulation of the built environment (primarily via regulation of the curb and regulation of off-street parking), this section focuses on the direct regulation of new mobility modes themselves, including shared bikes and scooters, TNCs, and AVs.

\subsection{FLEXIBLE REGULATION VIA PILOT PROGRAMS}

Pilot programs offer cities a potential means of regulating new mobility modes for a limited duration, allowing for program adjustments based on actual experience during the pilot, with adjustments taking place during the pilot program itself and/or during subsequent iterations of the program. Cities have used pilot programs for shared bikes (Seattle Department of Transportation 2018), scooters (City of Portland 2018), electric bikes (Seattle Parks and Recreation 2019), TNCs (City of Portland Bureau of Transportation 2015), and AVs (National League of Cities 2018).

Portland is one of the leading cities in the U.S. with regard to planning for e-scooter deployment. In July of 2018, Portland adopted an administrative rule establishing the Portland Bureau of Transportation's (PBOT) e-scooter policy, regulations, and permit requirements. This administrative rule was created pursuant to the authority of the State of Oregon's broad statutory definition of "vehicle” (“. . . any device in, upon or by which any person or property is or may be transported or drawn upon a public highway . . . includes vehicles that are propelled or powered by any means" Or. Rev. Stat. $\S$ 801.590 (2017)) and the Portland City Code's grant of authority to PBOT (Portland Bureau of Transportation 2018). The purpose of Portland's four-month 2018 pilot program was to assess the feasibility, safety, and mobility of e-scooters. In early 2019 , the City released its "2018 E-Scooter Findings Report" (Portland Bureau of Transportation 2019b). The City found that scooters were an overall positive addition to the city's transportation network, so much so that the City embarked on a second pilot program for scooters on April 26, 2019 based on the its findings and input from the community and regulators, revising its e-scooter rule accordingly (Portland Bureau of Transportation, 2019a). The current year-long pilot program rule gives the Director of PBOT the authority to make changes to the number of scooter permits allowed/allotted (overall or to particular permittees), and gives PBOT the authority to update the rule "at any time" (Portland Bureau of Transportation 2019a).

Like the City of Portland, the City of Santa Monica, California, has a robust pilot program that is governed by administrative regulations (City of Santa Monica 2019). The program gives the City broad oversight and control, with built-in mechanisms for adjusting the program expeditiously without City Council approval. The pilot program runs from September of 2018 through January of 2020 and is "subject to amendment during the Pilot Program as the City works with Operators to make data-driven decisions to deliver a safe transportation option and define effective solutions to known and identified challenges as the process evolves" (City of Santa Monica 2019). 
The Portland and Santa Monica pilot programs demonstrate the potential effectiveness of flexible administrative approaches to regulating emerging transportation technologies. Such programs allow cities the flexibility to adjust as needed to account for lessons learned during program implementation. The biggest potential downside to pilot programs may be the lack of predictability for both operators and users. However, it appears that having a program that can be adjusted to address real world conditions outweighs the inherent unpredictability that comes with pilot programs. It may be that program adjustments are actually somewhat predictable, inasmuch as operators and users will be on notice that programs adjustments are likely to be implemented whenever a pilot program has unanticipated negative outcomes.

\subsection{MICROMOBILITY: BICYCLES AND SCOOTERS}

\subsubsection{Bicycles}

The bikeshare phenomenon began in 1965 when a group of activists in Amsterdam left unlocked bicycles for anyone to use. The system, however, was considered a failure when many of the bikes were stolen. In 1996, the United Kingdom solved the theft problem when it introduced magnetic strip-card technology that allowed bicycles to be tracked when they weren't returned. With the growing public acceptance of bikeshare as a mass-transportation alternative in dense urban areas, many countries including France, Spain, and China have launched docked bike share systems. ("Dockless" micromobility systems do not require devices (bikes, scooters, etc.) to be secured at docks or kiosks by the user when the user is done using the device, while docked systems require the device to be secured at a dock or kiosk or impose an additional charge if it is not secured at a dock or kiosk.) This global trend did not arrive in the United States until 2010 when Washington, Minneapolis, and Denver introduced bike share technology to the American masses. Since then bike share has gained acceptance in many U.S. cities.

The acceptance of bicycles as a mass transit alternative is growing in popularity along with increasing concerns about the effects of automobility, including urban congestion, climate change, and health. Evidence suggests that bike-to-transit travel is popular with commuters in large, high-density areas. Bike share technology has adapted to shifting societal needs by ensuring a supply of docked and dockless bikes for anyone to rent.

Generally, to rent a bike share bicycle requires a credit card and either a smartphone app or a verified telephone number. Next, prospective riders locate the nearest bike and use an app, enter an access code, or swipe a credit card to unlock a bike for rental. When the rider has finished renting the bike, the rider can locate the nearest bike share dock through the app (if using a docked system), and lock the bike to the dock (or lock it according to applicable rules if dockless).

In some instances, instead of recognizing the positive externalities that dockless bike share systems offer, city residents have been upset by parked bikes that blocked driveways and sidewalks. In Seattle, for example, parking and right-of-way are the 
biggest public issues with regard to dockless bikes. Local governments have responded to these issues in different ways.

The Austin Transportation Department stopped issuing licenses to dockless bike share operators while collecting data and analyzing the level of demand. Austin did not have any laws penalizing dockless bike share operators, and did not specify bike parking requirements in its licensing application's terms and conditions.

Similarly, the San Francisco Municipal Transportation Agency (SFMTA) also stopped issuing dockless bike share permits, but allowed existing permit holders to continue their operation. However, in contrast to Austin, the City and County of San Francisco also passed an ordinance to abate, remove, and penalize operators who leave dockless bikes blocking public rights-of-way. In addition, the SFMTA through its permit application's terms and conditions specified parking requirements, including allowing parking in landscape and furniture zones.

Like San Francisco, Seattle also specified parking guidelines in its dockless bikeshare permit application and allowed parking on landscape and furniture zones of sidewalks, but took it a step further. If parking is not available on sidewalks or if no sidewalk is available, dockless bikes may be parked "in a safe location that does not impede other street use or obstruct pedestrians." Further, to help riders identify the proper parking areas, the Seattle Department of Transportation (SDOT) began repurposing sidewalks or furniture zones for dockless bike parking designated by painted surfaces. The paintonly parking is a demarcated 6'x10' parking area that does not impede public right-ofway. Moreover, the Seattle City Council passed an ordinance reallocating up to $\$ 500,000$ of bikeshare street and sidewalk use fees to SDOT to enforce bikeshare parking requirements.

In contrast with the three U.S. cities mentioned above, the Albuquerque City Council passed an ordinance before issuing its first bikeshare permit to implement minimum standards for shared active transportation programs (City of Albuquerque 2018). The ordinance set minimum terms and conditions to issue permits, approved shared demarcated drop zones for parking, and provided for fines for right-of-way violations. Notably, Albuquerque encourages flexible demarcated zones that may be used on weekdays only and others on weekends only (City of Albuquerque 2019).

A pattern with local governments is to issue contracts for docked bike systems and to issue permits or licenses for dockless systems. Initially, local governments spent millions of tax dollars to establish bikeshare systems and entice bikeshare operators to manage day-to-day operations. However, with the surging popularity of dockless systems, the financial viability of publicly-subsidized docked systems is in question. Rather than compete with dockless operators that may be backed or owned by the likes of Uber or Lyft, some publicly-subsidized docked systems have exited the market.

A secondary effect of issuing long-term contracts for docked systems (whether publiclysubsidized or privately owned) is exclusivity provisions barring other operators. In the San Francisco Bay Area, Motivate, a docked bikeshare operator that is owned by Lyft, 
has a ten-year exclusive contract. Jump, a dockless bike operator owned by Uber, wants to expand its dockless e-bike fleet, but Lyft is preventing the expansion based on its exclusive contract. Essentially, Uber argued that the exclusivity provision only applies to docked operators, but the court issued an injunction in favor of Lyft/Motivate's exclusive contract in July of 2019. A similar challenge occurred when Deco Bikes, a docked bikeshare operator with a ten-year exclusivity contract with San Diego, tried to prevent the expansion of dockless bike operators. In that case, the San Diego City Attorney issued guidance to the City Council stating that the contract at issue did not insulate Deco Bike from competition.

Electric bikes are currently far more prevalent in countries other than the U.S., but are likely to become increasingly common in the U.S. and cities should prepare for them accordingly. The manufacturing and initial sale of electric bicycles ("e-bikes") are regulated by the Federal Consumer Product Safety Commission. But the operation of e-bikes is governed at the state and local level. Of the fifty states, thirty-one have an ebike definition in state law, while nineteen have not distinguished e-bikes from other motorized vehicles such as mopeds and scooters. Of the thirty-one states that define ebikes, eleven have adopted a three-tiered speed limit classification. The State of Washington provides a good example of such a three-tiered classification, with "Class 1 " defined as including e-bikes for which electric assistance is provided only when the rider is pedaling and ceases at twenty miles per hour, "Class 2" defined as including ebikes for which electric assistance is provided even when the rider is not pedaling and ceases at twenty miles per hour, and "Class 3" defined as including e-bikes for which electric assistance is provided only when the rider is pedaling and ceases at twentyeight miles per hour. The City of Seattle is currently in the post-pilot analysis phase of a "Multi-Use Trail Pilot Project" where it allowed Class 1 and Class 2 e-bikes to be used on five multi-use trails. The pilot project included a 15-mph speed limit for e-bikes and "an education and outreach campaign on-trail use and etiquette" (City of Seattle 2019).

\subsubsection{Scooters}

Cities across the United States have recently experienced a new form of space-efficient, potentially low-carbon, personal mobility-e-scooters. E-scooters have created a new, affordable method of transportation for many people, and have created opportunities and challenges for local regulators, as well as for transportation planners. Initially rolled out in 2016, e-scooters entered major cities in 2017 , and have recently spread to midsized cities. E-scooter providers rapidly expanded, seemingly overnight, and large metropolitan areas suddenly had massive new transportation fleets available for public use without the need for public investment. These fleets of scooters often appeared without governmental approval.

Commentators note e-scooter companies followed in the footsteps of ride-hailing giants by adopting the "ask for forgiveness rather than permission" approach (Irfan 2018). In response, cities acted swiftly, with some banishing e-scooters, citing the lack of a business permit as the legal justification. Some cities also issued cease-and-desist orders based on the cities' internal development of comprehensive regulations for escooter devices (Irfan 2018). Recent trends indicate that e-scooter companies are now 
moving away from their initial disruptive model and negotiating agreements with local governments.

In order to have an understanding of why the regulation of e-scooters is important, it is vital to understand how they operate. Scooter users download an app to locate and unlock scooters, then pay to rent them by the minute. E-scooters are generally dockless and tracked by GPS, which enables users to park them virtually anywhere at the conclusion of a ride instead of returning them to a dock, kiosk, etc. (Mancuso 2019). It is important to note that e-scooter companies are able to use GPS to geofence the area in which their scooters can be operated and tracked, thereby creating invisible fences to limit service areas. This is a popular model that is also utilized by both dockless and docked bikeshare systems.

\subsubsection{Specific Recommendations}

To date, cities have largely attempted to respond to and regulate each new mode separately (shared bikes, e-bikes, scooters, etc.). The following regulations propose to discard these mode distinctions and adopt a broad definition of "micromobility" and "shared micromobility" that regulates based on the impact of the transportation device (low carbon, accessibility, safety (e.g. speed)). While a uniform definition is adopted, the regulations retain city authority to direct use of the right-of-way by requiring a permit. They also provide for prioritization of companies who provide services in alignment with city goals, such as equity and accessibility. The proposed mode-agnostic regulations recognize the changing nature of technology and recommend providing standing authority to adopt term-limited pilots to assess new shared mobility technology.

Finally, the proposed regulations seek to address issues of parking and operation by addressing the cause of the conflict-lack of space and infrastructure for these uses and users - by authorizing and directing funds to infrastructure and repurposing of rightof-way. We have identified twelve key areas for micromobility regulation:

1. Adopt broad mode-agnostic definition of micromobility transportation devices based on city goals and policies;

2. Define "shared mobility" broadly;

3. Regulate bicycles and micromobility devices as one transportation mode;

4. Rename bike lanes to be inclusive of other micromobility uses;

5. Require active reallocation of on-street parking;

6. Require permit to operate shared micromobility devices;

7. Give priority to providers that meet city goals;

8. Assess permit fee for shared mobility providers; 
9. Assess a per trip surcharge;

10. Direct fees for specific purposes; and

11. Parking standards for shared micromobility.

\subsubsection{Adopt broad mode-agnostic definition of micromobility transportation devices based on city goals and policies.}

Currently, Oregon defines bike, scooters, and electric personal assistive mobility devices all separately and therefore requires separate authorization to use bike lanes. In contrast, the following examples provide greater flexibility at capturing varying technologies.

\section{Model Existing Code Provision:}

"Motorized Mobility Device: A vehicle with a total weight of less than 75 pounds, equipped with or without handlebars, a floorboard for standing while operating, and two or three wheels; designed to transport only one individual; and manufactured with a power source capable of propelling the vehicle, unassisted on a paved level surface at a speed not to exceed fifteen (15) miles per hour, including, but not limited to, any such device owned and operated individually or operated through an agreement with a company." Decatur, Ga., Ordinance Amending Section 98 Traffic and Vehicles (2019), https://decatur.civicweb.net/document/3042.

\subsubsection{Define "shared mobility" broadly.}

Adopt regulations that apply to shared mobility devices broadly (versus limited to specific modes (e.g. electric bikes, electric scooters)). Note, the following example does not limit the definition of "shared mobility device" to any city goals such as carbon reduction or transportation equity.

\section{Model Existing Code Provision:}

"'Shared Mobility Device' shall mean any micromobility transportation device by which a person can be propelled, moved or drawn, that is displayed, offered or placed for rent in any public area or public-right-ofway except that a 'shared mobility device' does not include any device being vended or made available for rent exclusively from a vehicle pursuant to a valid City vending permit; a car share vehicle [], or device authorized by the City bike share system []; a taxicab []; a device operated by the Los Angeles County Metropolitan Transportation Authority; or any other device excluded pursuant to administrative regulations." Santa Monica, Cal., Municipal Code § 3.21.020(f). 


\subsubsection{Require permit to operate shared micromobility devices.}

Permit requirements provide an avenue to regulate the use of shared micromobility devices, impose conditions that can ensure consistency with city goals, and provide a means to impose fees.

\section{Model Existing Code Provision:}

"Notwithstanding any other provision of this Code, no person may: (a) Display, offer or make available for rent any shared mobility device within the City, unless the person has first obtained: (1) a valid shared mobility operator permit; and (b) Abandon a shared mobility device not authorized by this Chapter in the public right-of-way or a public area in such a way that the device is available for rent." Santa Monica, Cal., Municipal Code $\S$ 3.21 .030 (2019).

\subsubsection{Give priority to providers that meet city goals.}

This may include preference for providers that connect with public transit options and address equity and access issues.

\section{Model Existing Code Provision:}

"The City prefers a connected shared mobility system that increases the accessibility of other modes of transportation and builds upon a cohesive regional transportation network. Operators that provide a system that can interact with other modes of transportation, such as public transit, car sharing services, ride[-]hailing services, and existing bike share services, are preferred." Santa Monica, Cal. Municipal Code § 3.14.1 (2019).

\section{Model Existing Provision:}

"Th[e City's] pilot [program] has the following objectives:

1. Increase mode shift from automobiles, including single occupancy vehicle and private for hire;

2. Reduce barriers and increase access to Shared Scooters by people with low incomes, people of color, and people with disabilities;

3. Increase Permittees' employment of people with low incomes and people of color;

4. Support safe riding and safe walking conditions, including reducing scooter sidewalk riding and improper parking ...." (Portland Bureau of Transportation 2019a). 


\subsubsection{Assess permit fee for shared mobility providers.}

This may include a general grant of authority to assess fees and more specific requirements for fees for shared mobility providers. Portland provides a general grant and Portland Bureau of Transportation has set specific fees in its administrative rules.

\section{Model Existing Code/Administrative Provisions:}

"The Transportation Director and/or City Council may establish fees and charges." Portland, Or., Code $\S 16.10 .500$ (2019).

"The Applicant must pay an application fee of $\$ 500.00$." (Portland Bureau of Transportation 2019a).

\subsubsection{Assess a per trip surcharge.}

The fee assessed should be set to prioritize city goals. In the example given, Portland has tied its fees to promote equity in distribution of mobility options to low-income neighborhoods. Further, regulations should direct fees assessed towards improvement of infrastructure for micromobility devices.

\section{Model Existing Administrative Provision:}

"The Permittee must pay a Street Use Surcharge of $\$ 0.25$ for each booked trip. ... [and] a Right-of-Way Use Surcharge per Available Shared Scooter per day. The fee amount will be differentiated by the Pattern Area in which the Shared Scooter is Available. If a Shared Scooter is at any point Available in the Central City, the Right-of- Way Fee will be $\$ 0.20$ per scooter per day. If a Shared Scooter is not Available in the Central City but is at any point Available in the Inner Neighborhoods, Western Neighborhoods or Rivers Pattern Areas, the Right-of-Way Fee will be $\$ 0.10$ per scooter per day. If a Shared Scooter is only Available in East Neighborhoods Pattern Area, the Right-of-Way Fee will be \$0.05." (Portland Bureau of Transportation 2019a).

\subsubsection{Direct fees for specific purposes.}

Fees collected should be earmarked for defraying costs of administering micromobility programs, and for achieving city micromobility goals by improving micromobility access/ infrastructure.

\section{Model Administrative/Code Provisions:}

"Shared Scooter Fees, surcharges and penalties will be placed in a New Mobility Account and used for the following purposes: (1)The Application Fee will be used by PBOT for permit development and application review; 
(2) The Pilot Permit Fee will be used by PBOT for administration, enforcement, and evaluation; (3) The Street Use Surcharge and Right-ofWay Use Surcharge will be used by PBOT for safe travel infrastructure, dedicated parking, and expanding equitable access." (Portland Bureau of Transportation 2019a).

"The City Council may establish permit fees and charges by resolution, which shall: (1) Defray the City's costs in administering and enforcing the provisions of this Chapter; and (2) Reflect charges associated with use of public property pursuant to this Chapter." Santa Monica, Cal., Municipal Code $\S 3.21 .0505(b)(2019)$.

\subsection{TRANSPORTATION NETWORK COMPANIES}

Transportation network companies (also referred to as "ride-hailing services," "ridesharing companies," and "mobility service providers") provide transportation services using an online platform to connect passengers with drivers using their personal vehicles (State of California PUC 2019). The State of California was the first state to classify companies offering ride-hailing services as "transportation network companies" (State of California PUC 2013). As of July 2019, Uber and Lyft are the two largest companies commonly classified as TNCs in the United States, with Uber having a market share of $69.9 \%$ and Lyft at $28.3 \%$ (Second Measure 2019).

Both Uber and Lyft started operating fewer than ten years ago, with Uber dating to 2009 , and Lyft to 2012, at which time no state or local government had regulations addressing the type of services TNCs provided (TechCrunch 2010). In some markets, TNCs faced legal challenges from local governments as well as protests by local taxi companies (TechCrunch 2010). However, as TNC services surged in popularity, government officials began observing how TNCs affected congestion, parking, public transit use, etc. in the cities and states in which the companies operated (Marshall 2018; Badger 2017). The sudden and large-scale changes that TNCs visited on the roads of cities spurred state and local government officials to begin drafting laws to better regulate the services that TNCs provide.

When TNCs first started to operate in new cities, they generally employed the following strategy to launch services: first, they would enter a new market quickly and spend significant capital to develop customer and driver loyalty. Next, they employed individuals to lobby and meet with government officials and their staffs to advocate for the benefits of TNCs. TNCs would then issue ultimatums to city officials and leave cities entirely if the cities imposed regulations that the companies believed affected their business model, while encouraging customers to take action on the companies' behalf through in-app messages and petitions (Borkholder et al. 2018).

This disruptive strategy that TNCs employed reflected the companies' belief that existing taxi and private for-hire vehicle regulations did not apply to their business model (James 2018). Historically, local governments regulated taxis and for-hire private vehicles, imposing strict limits on licenses (James 2018). Because TNCs use mobile 
applications to pair drivers with a rider, determine a route, and set a price based on realtime supply and demand within the app, many existing taxi regulations simply did not include language empowering government officials to regulate TNCs (James, 2018).

Across the country, TNCs lobbied state governments to enact legislation favorable to the business model described above, advocating for regulations enabling the companies to operate statewide (i.e., without local regulation) (James 2018). These lobbying efforts were largely successful: as of 2019 , close to $90 \%$ of U.S. states have enacted TNC laws that impose some level of preemption on local government authority to regulate TNCs (BERK Consulting 2019). Only one state (Oregon) has no state-level TNC regulation, while four states (Illinois, Minnesota, Nebraska, and South Dakota) have state-level regulation with no local preemption, and Kentucky, New York, and Vermont have state-level regulation with exemptions for particular cities (BERK Consulting 2019).

The lobbying efforts of TNCs effectively led to three model frameworks for state regulation of TNCs:

1. a framework where state regulations serve as a floor for local regulation (i.e., local governments can adopt more stringent regulations);

2. a framework where state regulations act as a ceiling on local regulation (i.e., local governments cannot adopt more stringent regulations); and

3. a framework where state regulation allows localities to opt out of state regulation in favor of local regulation.

In states where state law allows local governments to regulate TNCs, local governments have drafted regulations that address particular issues that TNCs cause at the local level. The differences between local and state regulations highlight the different sets of issues that state and local governments prioritize when confronted with the advent of TNCs. State and local governments take different approaches, both aimed at addressing particular issues of concern posed by TNCs.

\subsubsection{State Regulation as a Floor}

The first framework that states have implemented to regulate TNCs is one where state regulation serves as a floor for local government regulation of TNCs (Borkholder et al. 2018). California, Connecticut, Kansas, Minnesota, Nebraska, South Dakota, and Washington all employ this model, with California having been the first state to do so (Borkholder et al. 2018). California designated TNCs as a separate classification under its Public Utilities Code, thereby retaining the state's power to implement laws regulating TNCs (CPUC 2019). In contrast to this state-level regulation of TNCs, local governments in California maintain exclusive jurisdiction to regulate taxicabs, specifically exempting them from state regulations (CPUC 2019). 
Although California law grants power to the state to regulate TNCs, the California Constitution does allow "a city or county [to] make and enforce within its limits all ... ordinances and regulations not in conflict with the general laws." Under California law, a local law conflicts with state law when the state legislature clearly intends to preempt local law (San Francisco County Transportation Authority 2017). Thus, local jurisdictions in California have the authority to regulate TNCs as long as regulatory provisions don't conflict with the state's regulatory framework for TNCs (San Francisco County Transportation Authority 2017).

Many cities and counties in California have implemented regulations addressing particular issues posed by TNCs within their jurisdictions (San Francisco County Transportation Authority 2017). For example, the City of San Francisco grants the San Francisco Municipal Transportation Agency (SFMTA) the authority to regulate curb use in the city, which allows it to designate specific curb zones as pickup and drop-off only in order to alleviate congestion caused by TNC pickups and drop-offs (San Francisco County Transportation Authority 2017). SFMTA regulations also prohibit TNC drivers from using transit/taxi lanes, and from picking up or dropping off passengers at bus stops (San Francisco County Transportation Authority 2017). Because California's state-level TNC regulation does not explicitly cover TNC pickup and drop-off of passengers, pickup and drop-off are fair game for regulation by SFMTA and other local jurisdictions in California (San Francisco County Transportation Authority 2017). In practice, most local governments regulate TNCs via code provisions that encompass all vehicles, and not provisions that are specifically targeted to TNCs.

The State of Washington is one of three states (the others being Louisiana and Minnesota) where insurance requirements are the only state-level TNC regulation. The lack of regulation of TNC operations by the state has resulted in "dozens of cities, two counties, and several airports outlin[ing] TNC requirements for companies and drivers .. . ranging from a memorandum of understanding (MOU) . . . to formal chapters in municipal code" (BERK Consulting 2019).

\subsubsection{State Regulation as a Ceiling}

A second framework that many states have implemented to regulate TNCs is one where state regulation acts as a ceiling for TNC regulations (Borkholder et al. 2018). Under this framework, utilized by over forty states, state regulation of TNCs preempts all local government regulation of TNCs, therefore TNCs need only to comply with one set of regulations for an entire state (Borkholder et al. 2018; BERK Consulting 2019).

The State of Texas provides an example of state regulation of TNCs that was a direct result of a local regulation opposed by TNCs (Samuels 2017). In December 2015, the Austin City Council passed an ordinance that required TNC companies to perform fingerprinting background checks on TNC drivers (Samuels 2017). Uber and Lyft, the two largest TNCs operating in Austin at the time, opposed the regulation and spent $\$ 9$ million in an attempt to get voters to overturn the regulation (Samuels 2017). The companies ceased operations in Austin when their efforts at overturning city regulation 
proved unsuccessful. However, the State of Texas subsequently established a statewide TNC regulatory framework that preempts local regulation (Liptak 2017).

Unlike the State of California's regulatory framework, which implicitly grants local governments some authority to regulate TNCs because it does not explicitly preempt all local authority, Texas law explicitly states that "regulation of transportation network companies, drivers logged in to a digital network, and vehicles used to provide digitally prearranged rides ... is an exclusive power and function of this state." Tex. Occ. Code Ann. $\S 2402$ (West 2017). The law further provides that a municipality or local entity may not regulate TNCs by imposing a tax; requiring an additional license or permit; setting rates; imposing operational or entry requirements; or imposing other requirements.

However, despite state preemption of local TNC regulation, the City of Austin has nonetheless managed to successfully implement laws to help reduce TNC congestion (Holland 2018). In 2018, the Austin Transportation Department repurposed four parking spots in front of a popular bar located on a busy transit corridor, converting the former parking spaces to a five-minute pickup/drop-off zone for all vehicle types (TNCs, commercial vehicles, and private vehicles) and vehicles had five minutes to pick up or drop off passengers in the zone (Holland 2018). This was done as a forty-five-day pilot program during which the city observed an increase in safer drop-offs and pickups taking place in the zone instead of in a travel lane, resulting in reduced congestion (Holland 2018). The City of Austin pilot program provides a model for local governments to develop creative solutions to TNC congestion, even in the face of a preemptive state government TNC regulatory framework.

\subsubsection{State Regulation with Exemptions for Local Jurisdictions}

A third framework that a number of states have implemented to regulate TNCs involves statewide regulation with some form of exemption for local jurisdictions. Alabama and New York allow local jurisdictions to opt out of their state laws by disallowing TNCs in their jurisdictions (i.e., local jurisdictions cannot independently regulate TNCs, but can ban them entirely) (BERK Consulting 2019). Maryland grandfathers local TNC assessments that were in place at the time the state enacted its TNC regulatory framework, and Nevada allows local government licensing requirements for TNCs (BERK Consulting 2019). The most common type of state TNC law exemption provision is one for airports, with at least thirteen states having some form airport exemption (lowa, Mississippi, Missouri, Nevada, New Mexico, New York, North Carolina, Ohio, Rhode Island, South Carolina, Tennessee, Texas, and Utah) (BERK Consulting 2019). Most of these airport exemptions are broadly applicable, though New Mexico's is limited to airports with more than one million passenger boardings per year (BERK Consulting 2019).

Kentucky, New York, and Vermont each have exemptions that apply to certain cities, with Kentucky's applying only to Louisville and limited to local regulation of driver qualifications, New York's applying only to New York City, and Vermont's applying only to Burlington (BERK Consulting 2019). New York's TNC law more broadly allows local 
governments to adopt generally-applicable limitations or restrictions relating to local traffic or parking control as authorized by state law, and also allows counties and cities located close to New York City to create reciprocity agreements so TNC drivers can pick up and drop-off passengers traveling between New York City and neighboring cities. N.Y. Veh. \& Traf. §§ 1691-1700 (McKinney 2017).

Even in the face of widespread state-level preemption of local TNC regulation, as discussed above, local jurisdictions are generally free to implement existing laws or legal authority to address the decreased need for parking and the increased need for curb management (e.g., parking repurposed as pickup/drop-off zones). Parking and curb management are discussed above in Section 5.0.

\subsubsection{Specific Recommendations}

Without regulations addressing TNC congestion and VMT impacts, TNCs have increased both congestion and VMT, adversely impacting city goals around sustainability (although TNCs' overall contributions are quite small compared with other private vehicle use and land use patterns and regulations). Given that TNCs have added to the congestion mix rather than alleviating congestion, we recommend a combination of land use policy and flexible street-level regulation to direct the adoption and use of TNCs in a manner that advances the goals of sustainability, reduction in vehicles miles traveled and associated carbon emissions, and community revitalization. We suggest five key policies in regulating TNCs:

1. State-level regulation setting regulatory floor;

2. Require TNCs to meet state sustainability goals;

3. Discard the distinction between TNC and taxis;

4. Prioritize pooled-ride for-hire vehicles;

5. Provide flexibility to manage curb by use and time; and

6. Apply TNC regulatory principles to all privately-owned vehicles.

\subsubsection{State-level regulation setting regulatory floor.}

We propose the adoption of state-level regulation that provides minimum regulatory standards but allows for increased regulation by local municipalities, with state regulation typically addressing insurance, safety, and data sharing.

\section{Model Existing State Statutory Language:}

"A unit of local government ... may not regulate transportation network companies, transportation network company drivers ... in a manner that is less restrictive than the regulation by the State under this Act." 625 Illinois Compiled Statutes 57/32 (2019). 


\subsubsection{Discard the distinction between TNC and taxis.}

Eliminate taxi zones and establish passenger pickup/drop-off zones that apply to both TNCs and taxis.

\section{Model Existing Code Provisions:}

"'Passenger loading zone' means a curbside street space designated on either a part-time or a full-time basis to permit vehicles to stop to load and unload passengers, either exclusively or concurrently with other uses." D.C. Code § 50-2661(4) (2019).

"'Prohibited pick-up and drop-off area' means a curbside street space designated near a passenger loading zone in which vehicles are prohibited from picking up and dropping off passengers during designated hours." D.C. Code § 50-2661(5) (2019).

\subsubsection{Provide flexibility to manage the curb by use and time.}

Regulate curb use by type of use and hours of use (including authority to prohibit passenger pickup/drop-off).

\section{Model Existing Code Provision:}

"Determine the location of and establish passenger load zones and in each case to fix the hours during which such zones shall be maintained open for the purpose for which the same are intended." Seattle, Wash., Municipal Code $\S 11.16 .280(C)(2019)$.

\subsection{AUTONOMOUS VEHICLES}

As with other modes, and perhaps even more acutely, AV technology has the potential to disrupt how we move through our communities. These changes could lead to lower carbon footprints, reduced congestion, reductions in private vehicle ownership, and increased density. Conversely, AVs have the potential to increase VMT, curb congestion, and sprawl, and decrease density. Regulation will play a key role in determining how $\mathrm{AVs}$ are implemented and their resulting effects on urban form, function, and quality-of-life. As such, while AV technology is still in the early stages of development and adoption, proactively planning for $\mathrm{AVs}$ will be critical to ensuring that AV adoption advances community goals and values.

Similar to TNCs, AV regulation involves a patchwork of federal, state, and local regulation. At the federal and state level, regulations have focused on safety, testing, data collection, insurance, liability, and licensing. Local regulations have focused on how AV technology is integrated into city transportation systems. 


\subsubsection{Federal Regulation}

At the federal level, the United States Department of Transportation has issued advisory policy guidance-Preparing for the Future of Transportation; Automated Vehicles 3.0and is working to develop a national regulatory framework. The guidance identifies six key principles for AV regulation: "prioritize safety; remain technology neutral; modernize regulations; encourage consistent regulatory and operational environment; prepare proactively for automation; and protect and enhance the freedoms enjoyed by Americans." The guidance also recognizes the key role for state and, in particular, local governments in regulating AVs. It notes that "local governments control a substantial part of the Nation's roadway and parking infrastructure, and have considerable influence over land use, via zoning and permitting," and recommends they consider how to "facilitate safe testing and operation" of AVs, how to manage the potential for increased congestion, and how to adjust to changing land use needs.

While the U.S. Congress has to date failed to pass comprehensive legislation regulating AVs, it is anticipated that federal legislation will eventually pass and, once adopted, will play a role in setting standards for the use of $\mathrm{AVs}$.

\subsubsection{State Regulation}

As of 2019, thirty-seven states have adopted regulations related to AVs. These regulations vary in what they authorize, with areas of regulation including the study of $\mathrm{AV}$ technology, testing of AVs, use of AVs within the state, and truck platooning (technology used to keep tucks together as a convoy). The regulations also vary in terms of the level of AV technology they address (levels range from zero ("no automation") to six ("full automation)). For instance, twelve states authorize the use of AVs without a human driver in the vehicle. Other states have chosen to require a human driver behind the wheel or a human driver in the vehicle.

Some states have also chosen to preempt aspects of local regulation-typically directed at preventing local governments from banning AVs entirely or imposing overly-onerous regulations that would effectively prevent adoption of $\mathrm{AV}$ technology within the municipality. For example, Tennessee adopted SB 598 in 2015, which prohibits a local government from banning AVs within their jurisdiction:

"No political subdivision may by ordinance, resolution, or any other means prohibit the use of a motor vehicle within the jurisdictional boundaries of the political subdivision solely on the basis of being equipped with autonomous technology if the motor vehicle otherwise complies with all safety regulations of the political subdivision. ... 'Autonomous technology' means technology installed on a motor vehicle that has the capability to drive the vehicle without any supervision by a human operator." Tenn. Code Ann. § 55-8-202 (2019).

In contrast, the governor of Massachusetts issued an executive order that authorized testing only with support from municipalities. "As existing motor vehicles laws neither 
expressly allow nor expressly prohibit the testing of highly automated vehicles on public roadways in the Commonwealth, MassDOT, with input from the AV Working Group and other technical experts as deemed appropriate, shall issue guidance ('Guidance') to allow for the safe testing of such technologies on designated state highways and on other public roadways in municipalities that desire to permit such testing." (Executive Order No. 572, 2016).

\subsubsection{Local Regulation}

Despite this patchwork of federal and state regulation there is still an important role for local regulation of $A V s$. At this early stage of the technology, most local regulation has come in the form of pilot programs. Existing pilots fall into three basic categories: (1) publicly-managed fixed-route shuttles; (2) privately-managed flexible route shuttles; and (3) freight delivery. Pilot programs provide an opportunity for cities to understand the impacts of AVs. For instance, while California permitted AV testing within the state, San Jose County started a pilot program with AV companies in which the county would partner with AVs to study impacts of the technology on the city's transportation system. The county incentivized participation by providing access to curbside pickup/drop-off zones and electric charging stations. In return, AV companies provided city access to data and aligned their deployment of vehicles with the city's schedule (San José Mayor's Office of Technology \& Innovation, 2019).

While the majority of local regulations have been focused on testing, some cities have begun to integrate $\mathrm{AV}$ technology into city planning and code. The City of Portland has adopted goals and policies in its comprehensive land use plan that will guide the adoption of AVs. In another example, the City of Chandler, Arizona, recognizing the impacts to parking from AVs, has amended its city code to allow for offsets to minimum parking requirements where developments include pickup/drop-off spaces.

\subsubsection{Specific Recommendations}

While AV technology continues to be in the development stage, it is critical that regulators proactively lay the regulatory foundation that will guide the adoption of $A V s$ in alignment with local and regional goals. An initial priority for cities should be to articulate their goals for AV technology in order to drive integration of AVs into the use of right-of-way.

1. Adopt city policy governing city's priority in integrating AVs on public right-of-way;

2. Broaden definition of services that are authorized to use drop-off/pickup zones to include AVs;

3. Authorize reduction of parking requirements if pickup/drop-off area is provided; and

4. Delegate authority to designate right-of-way. 


\subsubsection{Adopt city policy governing city's priority in integrating AVs on public right-of-way.}

\section{Model Existing Policy:}

"Prioritize connected and automated vehicles that are fleet/shared ownership, fully automated, electric and, for passenger vehicles, shared by multiple passengers (known by the acronym FAVES). Develop and implement strategies for each following topic.

9.68.a. Ensure that all levels of automated vehicles advance Vision Zero by operating safely for all users, especially for vulnerable road users. Require adequate insurance coverage for operators, customers, and the public-atlarge by providers of commercial connected and autonomous vehicle services.

9.68.b. Ensure that connected and automated vehicles improve travel time reliability and system efficiency by: (1) maintaining or reducing the number of vehicle trips during peak congestion periods; (2) reducing low occupancy vehicle trips during peak congestion periods; (3) paying for use of, and impact on, Portland's transportation system including factors such as congestion level, vehicle miles traveled, vehicle occupancy, and vehicle energy efficiency; and (4) supporting and encouraging use of public transportation.

9.68.c. Cut vehicle carbon pollution by reducing low occupancy "empty miles" traveled by passenger vehicles with zero or one passengers. Prioritize electric and other zero direct emission vehicles operated by fleets and carrying multiple passengers.

9.68.d. Make the benefits of automated mobility available on an equitable basis to all segments of the community while ensuring traditionally disadvantaged communities are not disproportionately hurt by connected and autonomous vehicle use. This includes people with disabilities, as well as communities of color, women, and geographically underserved communities.

9.68.e Identify, prevent, and mitigate potential adverse impacts from connected and automated vehicles. Connected and Automated Vehicles Tools. Use a full range of tools to ensure that connected and automated vehicles and private data communications devices installed in the City right of way contribute to achieving Comprehensive Plan and Transportation System Plan goals and policies.

9.69.a. Maintain City authority to identify and develop appropriate data sharing requirements to inform and support safe, efficient, and effective management of the transportation system. Ensure that when connected and automated vehicles use City rights-of-way or when vehicles connect with smart infrastructure within the City they share information including, but not limited to, vehicle type, occupancy, speed, travel routes, and travel times, with 
appropriate privacy controls. Ensure that private data communications devices installed in the City right of way are required to share anonymized transportation data.

9.69.b. Design and manage the mobility zone, curb zone, and traffic control devices, e.g. to limit speeds to increase safety, to minimize cut-through traffic, evaluate future demand for pick-up and drop-off zones, and to prioritize automated electric vehicles carrying more passengers in congested times and locations;

9.69.c. Evaluate the public cost and benefit of investments in wayside communication systems serving connected and automated vehicles. Develop a criteria-driven automated vehicle wayside infrastructure investment plan.

9.69.d. Develop sustainable user-pays funding mechanisms to support connected and automated vehicle infrastructure and service investments, transportation system maintenance, and efficient system management.

9.69.e. Ensure that automated vehicles and vehicles that connect to smart City infrastructure, and private data communications devices installed in the City right of way, help pay for infrastructure and service investments, and support system reliability and efficiency. Develop a tiered pricing structure that reflects vehicle impacts on the transportation system, including factors such as congestion level, vehicle miles traveled, vehicle occupancy, and vehicle energy efficiency." (City of Portland 2018).

\subsubsection{Broaden definition of services that are authorized to use drop- off/pickup zones to include AVs.}

Access to drop-off/pickup zones should be inclusive of AVs.

\section{Model Existing Code Provision:}

''Passenger loading zone' means a curbside street space designated on either a part-time or a full-time basis to permit vehicles to stop to load and unload passengers, either exclusively or concurrently with other uses." D.C. Code $\S 50-2661$ (4) (2019).

\subsubsection{Authorize reduction of parking requirements if pickup/drop-off area is provided.}

For cities that retain off-street parking minimums, providing pickup/drop-off areas can be incentivized by allowing for reduced minimums.

Model Existing Code Provision: 
"(1) Applicability. The intent of this Section is to encourage the installation of passenger loading zones to meet demand for passenger drop-off and pickup areas generated by ride sharing and/or autonomous vehicles on all land uses except single family residential.

(2) Number of passenger loading zones and correlated parking reduction. The number of parking spaces required in [insert section] may be reduced by ten (10\%) percent for each passenger loading zone space provided in accordance with the following table up to a maximum of forty (40\%) percent.

\begin{tabular}{|l|l|}
\hline Commercial & $\begin{array}{l}1 \text { loading zone space per } 50,000 \\
\text { sq. ft. }\end{array}$ \\
\hline General Office & $\begin{array}{l}\text { loading zone space per } 100,000 \\
\text { sq. ft. }\end{array}$ \\
\hline Industrial & $\begin{array}{l}1 \text { loading zone space per } 200,000 \\
\text { sq. ft. }\end{array}$ \\
\hline Institutional and Medical & $\begin{array}{l}1 \text { loading zone space per } 50,000 \\
\text { sq. ft. }\end{array}$ \\
\hline Multiple Family & 1 loading zone space per 150 units \\
\hline
\end{tabular}

(a) Passenger loading zone calculations shall be based on building gross square feet and shall be rounded to the nearest whole number. Loading zone spaces exceeding the number of spaces identified herein shall not be eligible for a ten (10\%) percent parking reduction." Chandler, Ariz., Municipal Code § 35-1808 (2019).

\subsubsection{Delegate authority to designate right-of-way.}

This provision provides flexibility to respond to new emerging technologies that may require new road patterns. For example, this would allow the creation of separate lanes for zero-emission AVs or provide regulatory authority to manage increase in ecommerce (allowing delivery by only certain types of vehicles for certain hours).

\section{Model Existing Code Provision:}

"Designate transit lanes and street locations where certain transit vehicles may proceed in a manner prohibited to other traffic." Portland, Or., Code $\S$ 16.10.200(K) (2019). 


\subsection{STRONGER POLICY SUGGESTIONS}

In addition to the policies and codes above drawn largely from existing municipal documents, below are bolder suggestions for policies. Sometimes, looking at existing policy is insufficient for fully understanding what direction to take because existing policy usually reflects incremental change and understanding our cities and streets as they are. Yet, with the introduction of so many new mobility technologies that have the potential of widespread disruption - potentially in good or destructive ways - looking at possible policies that can help cities leapfrog into new patterns of development and decision making can be helpful. The following ideas are presented in that spirit.

\section{Explicitly describe the right of way.}

The street right of way is publicly owned and thus local municipalities (usually) control this valuable mobility pipeline. The street right of way also generally represents the largest area of a city's public space. Thus, cities have enormous leverage on the uses and transportation modes that are prioritized. With new transportation technologies, in addition to potential future needs for disease-based social distancing, explicitly defining the purpose and hierarchy of uses within a street right of way can help guide modal goals. Given the generally fixed size of the transportation pipeline, we suggest a right of way policy that emphasizes space-efficient movement.

\section{Model Suggested Right-of-Way Policy:}

[Agency] decisions regarding right-of-way allocation, design, investment, and construction shall be made based on the priority uses and functions identified in [identify city priorities]. Where mobility is identified as a priority function, decisions shall be made by applying the city's hierarchy of transportation modes. In all cases, decisions regarding right-of-way allocation should prioritize space-efficient modes of transport (ratio of vehicle size to average occupancy level) and should be made to advance the city's sustainability, environmental, equity, and household affordability goals. [Identify applicable policy citations].

\section{Designate 'curb zones' or 'curb lanes'.}

Rename former curbside parking zones to something less parking-centric and more reflective of the various uses of the curb other than/in addition to parking, for example "curb use zones" or "curb lanes". These zones may be for restaurant seating, bioswales, bike or scooter parking, pickup and dropff sites, dedicated bus or bike lanes, traditional travel lanes, traditional vehicle parking uses, or some combination. In curb-protected bike/scooter lanes, the curb zone refers to the 'inside' curb - the part that is closest to the middle of the street right of way. 
Add nimble flexibility to curb zone parking decisions.

Model Suggested Code Provision to Authorize Municial Agency to set Curb Zone Use:

The [Agency] may designate the curb zones for all public rights-of-way and in each case identify the hours when the specific zone applies. The [Agency] may prohibit specific uses within specific zones.

Model Suggested Code Provision to set fees for curb use:

The [designated decision maker] may establish pay parking meter zones.

\section{Model Suggested Policy to direct parking fees collected toward particular purposes:}

$\mathrm{X} \%$ of parking revenue collected shall be directed toward establishment of new non-automobile infrastructure or maintenance and improvement of existing non-automobile infrastructure.

\section{Model Suggested Policy to Rebalance Parking to Space-Efficent Micromobility:}

The local transportation authority is required to provide at least one carparking-sized space per side of each block to micromobility parking. Spaces converted under this provision can include fixed objects to local devices to, docking stations, or dockless micromobility parking for both shared and private micromobility devices. All spaces shall include painting that identifies them as available for micromobility parking.

\section{Model Suggested Policy for Parking standards for shared micromobility:}

Shared micromobility devices shall be parked in designated parking locations where one is available on the block face. A designated parking area is one that has been delineated by signage or has fixed corrals or racks. Where space is not available within the designated parking area, or no designated parking area is available, a user may park a micromobility device: (1) in any vehicle parking place of any kind (except for designated spots for people with disabilities or temporary loading or unloading zones) and pay any applicable meter fees, if applicable; (2) in any location on the sidewalk that does not block ADA-required sidewalk space; or (3) at an existing bike parking location.

Model Suggested Policy for demand-based parking rates for private automobiles: 
The [Agency] is authorized to establish pay parking zones and to adjust parking rates to meet occupancy targets of $85 \%$. Minimum parking rate is set at $\$ X . X X /$ hour. The [Agency] is authorized to increase rates by Y.YY/hour where parking occupancy rates exceed occupancy targets.

\section{Other Parking}

\section{Model Suggested Policy to Eliminate Parking Minimums for Motorized Vehicles:}

The City is hereby prohibited from requiring minimum car parking spaces.

\section{Model Suggested Policy to Permit the conversion of existing off- street parking spaces to other uses.}

Existing off-street automobile parking may be eliminated and converted to new uses where parking minimums have been removed or the existing parking spaces exceed the minimum number of parking spaces required under current regulation. The property owner must maintain existing levels of all other types of parking. Where the property owner does not meet current micromobility parking, greenscaping, and public transit requirements, the property owner must first convert excess parking spaces under this provision to meet current regulatory requirements prior to converting spaces for a private use.

\section{Model Suggested Policy to Establish parking maximums for new and existing development.}

Existing development shall not be permitted to expand off-street parking above and beyond maximum parking limits imposed on new development.

\section{Model Suggested Policy to Add flexibility parking minimums.}

Landowners may meet existing car parking requirements by providing parking for micromobility, pick-up / drop-off, motorcycle, private cars or some combination thereof. Up to $100 \%$ of existing car parking spaces can be converted to micromobility parking using a ration of 1:1 - for every one car parking removed, one micrombility parking space needs to be added.

\section{Regulate bicycles and micromobility devices as one transportation mode.}

States have frequently differentiated between bicycles and other electric personal transportation devices in regulations. For example, in Oregon bicyclists are allowed to operate on sidewalks except where prohibited by local ordinance. Bicyclists on sidewalks are subject to the same rights and responsibilities as pedestrians. ORS $\S 814.410(2)$. On the other hand, electric-assisted bicycles are prohibited from operation on all sidewalks. ORS $\S 814.410(1)(e)$. It is 
important to note that regulatory provisions should include authority to restrict usage of public spaces by micromobility devices for safety purposes. For example, due to density concerns, Portland prohibits the use of electric bicycles in downtown core areas.

\section{Model Suggested Policy to Regulate bicycles and micromobility devices as one transportation mode:}

Micromobility devices shall be treated the same as bicycles under the following provisions: [identify targeted statutory and code provisions addressing bicycles].

\section{Rename bike lanes to be inclusive of other micromobility uses.}

What cities currently typically call "bike lanes" should be renamed to be inclusive of other forms of micromobility in addition to bikes. One example could be 'SMILE Lanes", or Shared Mobility Integration Lanes with Emergency access (see: https://blogs.uoregon.edu/transport/smile-lane-design-competition/.)

\section{Model Suggested Policy to Rename bike lanes to be inclusive of other micromobility uses:}

"Bike lanes" shall be renamed "micromobility lanes," and references to "bike lanes" in codes, plans, etc. shall be considered to refer to micromobility lanes.

\section{Apply micromobility regulatory principles to all privately-owned vehicles.}

Given the status quo, where a majority of trips are taken by single-occupancy private vehicles, policy and regulations aimed at regulating the speed and geography of dockless scooters and bikeshare should be equally applied to private motorized vehicles. For example, if a city desires to limit scooter speed overall or in certain areas, then the same requirement must be placed on automobile manufacturers whose products also operate within the regulatory jurisdiction. If regulations require scooter companies to be responsible for the appropriate parking of its devices and fined if parked illegally, then the same standard must be applied to on automobile manufacturers whose products also operate within the regulatory jurisdiction. That is, either micromobility modes should be able to operate under the standards applied to motorized vehicle usage or the standards of automobile usage must be updated to be consistent with new mobility. The public owns the street right of way and can regulate that space to achieve desired community goals.

\section{Apply TNC regulatory principles to all privately-owned vehicles.} Given the status quo, where a majority of trips are taken by single-occupancy private vehicles, policy and regulations aimed at reducing VMT, excessive vehicle vacancy, and consolidation of parking of TNCs ought to be applied equally to all automobile users, whether privately owned or private-company provided. Applying higher performance standards for new mobility modes without applying similar expectations toward the main 
cause of transportation-based greenhouse gas production, public health impacts, social division, pollution, and land consumption represents a double standard that makes it harder to meet municipal goals.

Prioritize pooled-ride for-hire vehicles.

Establish passenger pickup/drop-off zones exclusively for pooled-ride or multiple passenger vehicles.

\section{Model Suggested Code Provisions for Prioritizing pooled-ride for- hire vehicles:}

"Pooled passenger loading zone" means curbside space designated exclusively on either a part-time or full-time basis to permit pooled rides vehicles to stop to load and unload passengers. (Modeled on D.C. Code $\S$ 50-2661(4) (2019).

"Pooled ride for-hire vehicle" means any private for-hire vehicle that will carry more than a single passenger whether that is in one party or where the overall vehicle trip will offer shared rides to multiple independent parties.

\section{Regulate TNCs to meet sustainability goals.}

Governments should regulate TNCs to support sustainability and climate policies by requiring fleet electrification, by requiring TNC apps to connect with public transit, and by requiring reduction in VMT without passengers.

\section{Model Suggested Local (or State) Policies to Regulate TNCs to meet sustainability goals:}

Implement a "cruising cap," requiring reduction of the amount of time TNCs spend idling to [insert percentage]\% within six months and to [insert percentage]\% within a year (reduction based on pre-cap estimated cruising/idling). (Modeled after New York City Taxi \& Limousine Commission policy calling for reduction to $36 \%$ in six months, $31 \%$ within a year, and a pre-cap estimate of $41 \%$.)

Require additional data for congestion management, including data concerning "time spent and ... miles driven by TNC drivers" in designated geographic areas and/or during designated time periods, with time and miles broken down by time spent/miles driven en route to pickups, time spent/miles driven transporting customers, and time spent/miles driven logged in to the TNC system but neither en route to pickups or transporting customers. (Proposed Massachusetts Senate Bill S.2289)

Require the creation and implementation of a program to increase the use of zero-emissions vehicles by TNCs. (California Senate Bill 1014, 
California Clean Miles Standard and Incentive Program: zero-emission vehicles.)

Require inclusion of the ability to connect to other modes such as public transit and micromobility options within TNC apps. 


\subsection{CONCLUSION}

Many U.S. cities have been or are at the forefront of developments in "new mobility" in recent years (oftentimes inadvertently), initially with transportation network companies (TNCs) (e.g., Uber, Lyft), and more recently with various forms of "micromobility" (e.g., shared bikes and scooters). This new mobility has a different set of requirements and impacts from those of "old" auto-centric mobility. For example, TNCs generally require less parking than traditional privately-owned vehicles, along with an associated increase in the need for pickup and drop-off locations. As shared bikes and scooters dramatically increase in utilization across the country, there is a need for appropriate infrastructure to ride and park them. In the near future, shared fleets of autonomous vehicles will likely accelerate individual mobility patterns from the current system based largely on owneroccupied, private automobility to one of Mobility as a Service (MaaS). With MaaS, individuals will buy rides in vehicles, or use shared or individually-owned, spaceefficient, low-carbon micromobility modes, rapidly impacting allocation of street right of way and the utilization of on- and off-street parking. All of these changes will require new conversations about public infrastructure and local land use.

At the same time as this rise in new mobility, cities have increasingly set their sights on achieving various goals related to GHG emissions, active transportation, pedestrian and cyclist safety, equity, air pollution, household affordability, urban stormwater treatment, etc. Many of these goals have direct and indirect connections to new mobility. New mobility presents cities with opportunities to implement new mobility technologies not merely in harmony with, but in furtherance of numerous municipal goals. Properly implemented by cities, new mobility offers the promise of less congestion, reduced carbon and other fossil fuel-associated emissions, increased health and safety, more equitable access to cities, etc.

Yet, while the mobility environment is rapidly changing, led mostly by private sector innovations in ride hailing and scooter use, the ability of local government to direct these new modes to maximize the social good and minimize the social bad, often happens at a slower speed than the technological innovation. Given these rapid mobility changes and the impact of these modes on almost all aspects of the form and function of cities, it is important to help local government match the speed of the technological change with the speed of decision making. This report analyzes and extracts the current best municipal practices around new mobility, synthesizes them for easier local practitioner access, and extends them into new potential legal and policy tools for municipalities to use in an effort to proactively anticipate large-scale impacts from new mobility and guide the change to maximize community goals. 


\subsection{REFERENCES}

Badger, Emily 2017. "Is Uber Helping or Hurting Mass Transit?" The New York Times, October 16, 2017. https://www.nytimes.com/2017/10/16/upshot/is-uber-helping-orhurting-mass-transit.html

BERK Consulting. 2019. Policy Guide: Regulation of Transportation Network Companies.

http://leg.wa.gov/JTC/Documents/Final\%20Studies/TNC_PolicyGuideFinal.pdf.

Bierstedt, J., Gooze, A., Gray, C., Peterman, J., Raykin, L., \& Walters, J. (2014). Effects of next-generation vehicles on travel demand and highway capacity. FP Think Working Group, 10-11.

Borkholder, Joy, Mariah Montgomery, Miya Saika Chen, and Rebecca Smith. 2018. Uber State Interference: How Transportation Network Companies Buy, Bully, and Bamboozle Their Way To Deregulation. National Employment Law Project and Partnership for Working Families.

. https://www.nelp.org/wp-content/uploads/Uber-State-Interference-How-TransportationNetwork-Companies-Buy-Bully-Bamboozle-Their-Way-to-Deregulation.pdf.

California State Assembly, Assembly Bill 904 (AB 904) 2012

Childress, S., Nichols, B., Charlton, B., \& Coe, S. (2015). Using an activity-based model to explore the potential impacts of automated vehicles. Transportation Research Record, 2493(1), 99-106.

CPUC 5430

https://leginfo.legislature.ca.gov/faces/codes_displayText.xhtml?lawCode=PUC\&divisio $n=2 . \&$ title $=$ \&part $=\&$ chapter $=8$ \&article $=7$.

CPUC 5353

https://leginfo.legislature.ca.gov/faces/codes_displayText.xhtml?lawCode=PUC\&divisio $\mathrm{n}=2$.\&title $=$ \&part $=\&$ chapter $=8$.\&article $=1$.

Chase, Robin. 2018. "If Your Car Is Stuck in Traffic, It's Not Uber and Lyft's Fault." CityLab, July 27, 2018. https://www.citylab.com/transportation/2018/07/dont-blame-ridehailing-for-traffic-congestion/566222/.

City of Albuquerque. 2018. Shared Active Transportation Ordinance.

http://library.amlegal.com/nxt/gateway.dll/New\%20Mexico/albuqwin/cityofalbuquerquen ewmexicocodeofordinanc?f=templates $\$ f n=$ default.htm $\$ 3.0 \$ v i d=a m l e g a l: a l b u q u e r q u e \_n$ m_mc 
City of Albuquerque. 2019. Shared Active Transportation Program FAQs. https://www.cabq.gov/planning/shared-active-transportation/shared-activetransportation-program-faqs.

City of Minneapolis. 2019. Minneapolis 2040. https://minneapolis2040.com/pdf/.

City of Oakland Department of Transportation. 2019. The Year in Review: 2018 Shared Mobility Snapshot. https://medium.com/oakdot/the-year-in-review-2018-shared-mobilitysnapshot-3ed9d34234e6

City of Portland. 2018. 2035 Comprehensive Plan. https://www.portlandoregon.gov/bps/57352.

City of Santa Monica. 2019. Shared Mobility Device Pilot Program Administrative Regulations.

https://www.smgov.net/uploadedFiles/Departments/PCD/Transportation/SMAdminGuidelines_03-05-2019_Final.pdf.

City of Seattle. 2019a. Flex Zone/Curb Use Priorities.

https://www.seattle.gov/transportation/projects-and-programs/programs/parkingprogram/parking-regulations/flex-zone/curb-use-priorities-in-seattle.

City of Seattle. 2019b. Seattle Right-of-Way Improvements Manual. https://www.seattle.gov/rowmanual/manual/.

City of Seattle. 2018. Seattle 2035 Comprehensive Plan. https://www.seattle.gov/Documents/Departments/OPCD/Ongoinglnitiatives/SeattlesCo mprehensivePlan/CouncilAdopted2018_TOC.pdf.

Davidson, Michael and Fay Dolnick., eds. 2002. Parking Standards. Chicago: American Planning Association, Planning Advisory Service.

Descant, Sid. 2018. "San Francisco Rolls Out Dynamic Parking Rate Model." Government Technology. https://www.govtech.com/fs/automation/San-Francisco-RollsOut-Dynamic-Parking-Rate-Model.html

Fagnant, D. J., \& Kockelman, K. M. (2014). The travel and environmental implications of shared autonomous vehicles, using agent-based model scenarios. Transportation Research Part C: Emerging Technologies, 40, 1-13.

Fehr \& Peers. 2018. San Francisco Curb Study. https://www.fehrandpeers.com/wpcontent/uploads/2019/01/SF_Curb_Study_2018-10-19_web-download.pdf.

Fehr \& Peers. 2019a. Cincinnati Curb Study. http://www.fehrandpeers.com/wpcontent/uploads/2019/01/CincinnatiCurbStudy_2019-01.pdf. 
Fehr \& Peers. 2019b. Estimated TNC Share of VMT in Six US Metropolitan Regions (Revision 1).

https://drive.google.com/file/d/1FIUskVkj9IsAnWJQ6kLhAhNoVLjfFdx3/view

Hanson, Susan, and Genevieve Giuliano, eds. 2004. The Geography of Urban Transportation. New York: Guilford Press.

Holland, Ben. 2018. "How a Loading Zone Can Facilitate Personal Mobility Services and Promote Safety." Rocky Mountain Institute, October 1, 2018. https://rmi.org/personalmobility-and-safety/.

Irfan, Umair, "Electric scooters' sudden invasion of American cities, explained," Vox September 7, 2018 https://www.vox.com/2018/8/27/17676670/electric-scooter-rentalbird-lime-skip-spin-cities

Institute of Transportation Engineers. 2018. Curbside Management Practitioners Guide. https://www.ite.org/pub/?id=C75A6B8B-E210-5EB3-F4A6-A2FDDA8AE4AA

James, Owain. 2018. "Uber and Lyft are lobbying states to prohibit local regulation." Mobility Lab, July 24, 2018. https://mobilitylab.org/2018/07/24/uber-and-lyft-arelobbying-states-to-prohibit-local-regulation/.

The League of American Bicyclists. 2017. Where We Ride: Analysis of Bicycle Commuting in American Cities.

Liptak, Andrew. 2017. "Lyft and Uber will return to Austin on Monday." The Verge, May 27, 2017. https://www.theverge.com/2017/5/27/15705060/lyft-uber-returning-austintexas-fingerprinting-requirements.

Litman, Todd. 2017. Short and Sweet: Analysis of Shorter Trips Using National Personal Travel Survey Data. Victoria Transport Policy Institute.

https://www.vtpi.org/short_sweet.pdf

Mancuso, Kate. 2019. "The Rise of Electric Scooter Regulations." The Regulatory Review, January 3, 2019.

Marshall, Aarian. 2018. "Uber and Lyft Made Traffic Worse in San Francisco. But It's Complicated." Wired, October 16, 2018. https://www.wired.com/story/uber-lyft-sanfrancisco-traffic-report/.

National Association of City Transportation Officials. 2019. Shared Micromobility in the U.S.: 2018.

National League of Cities. 2018. Autonomous Vehicle Pilots Across America. https://www.nlc.org/resource/autonomous-vehicle-pilots-across-america. 
Portland Bureau of Transportation. 2015. Private For-Hire Transportation Innovation Pilot Program: Transportation Network Service Guiding Regulatory Principles. https://www.portlandoregon.gov/transportation/article/526684.

Portland Bureau of Transportation. 2018. Administrative Rule TRN-15.01. https://www.portlandoregon.gov/transportation/article/726365.

Portland Bureau of Transportation. 2019a. Administrative Rule TRN-15.01. https://www.portlandoregon.gov/citycode/article/690212.

Portland Bureau of Transportation. 2019b. 2018 E-Scooter Findings Report. https://www.portlandoregon.gov/transportation/article/709719.

Pyzyk, Katie. 2018. "Managing the curbside in the age of e-commerce and congestion." Smart Cities Dive. https://www.smartcitiesdive.com/news/curbside-ecosystem-ecommerce-congestion-ups/517347/.

San Francisco County Transportation Authority. 2017. The TNC Regulatory Landscape: An Overview of Current TNC Regulation in California and Across the Country. https://www.sfcta.org/sites/default/files/2019-03/TNC_regulatory_020218.pdf.

Schaller Consulting. 2019. Ride Service and Taxi Ridership, 1990-2018. http://www.schallerconsult.com/rideservices/favfact1.htm.

Schoettle, B., \& Sivak, M. (2014). A survey of public opinion about autonomous and self-driving vehicles in the US, the UK, and Australia. University of Michigan, Ann Arbor, Transportation Research Institute.

Seattle Department of Transportation. 2017. New Mobility Playbook. https://www.seattle.gov/Documents/Departments/SDOT/NewMobilityProgram/NewMobil ity_Playbook_9.2017.pdf.

Seattle Department of Transportation. 2018. 2017 Free-Floating Bike Share Pilot Evaluation Report.

http://www.seattle.gov/Documents/Departments/SDOT/BikeProgram/2017_BikeShare_ Evaluation_Report_113018.pdf.

Seattle Parks and Recreation. 2019. Multi-Use Trail Pilot Project.

https://www.seattle.gov/parks/about-us/current-projects/multi-use-trail-pilot-project.

Second Measure. 2019. Uber vs. Lyft: Who's tops in the battle of U.S. rideshare companies. https://secondmeasure.com/datapoints/rideshare-industry-overview/.

Shoup, Donald. 2005. The High Cost of Free Parking. Chicago : Planners Press, American Planning Association.

Shoup, Donald. 2015. "Putting a Cap on Parking Requirements." Planning 81 no. 5 (May): 28-30. 
Strong Towns. 2018. More Cities Than Ever Are Eliminating Parking Minimums. https://www.strongtowns.org/journal/2018/11/23/a-map-of-cities-that-got-rid-of-parkingminimums-updated.

State of California Public Utilities Commission, Basic Information for Transportation Network Companies and Applicants (revised July 9, 2019) https://www.cpuc.ca.gov/uploadedFiles/CPUC_Public_Website/Content/Licensing/Trans portation_Network_Companies/BasicInformationforTNCs.pdf.

State of California Public Utilities Commission, Decision Adopting Rules and Regulations to Protect Public Safety While Allowing New Entrant to the Transportation Industry (Decision 13-09-045 September 19, 2013) http://docs.cpuc.ca.gov/PublishedDocs/Published/G000/M077/K192/77192335.PDF.

State of Washington, Revised Code of Washington, 46.04.169, 2019

Superior Court for the State of California for the County of San Francisco, Order Granting Plaintiff Bay Area Motivate, LLC's Motion for Preliminary Injunction, July 23, 2019.

TechCrunch. 2010. UberCab Ordered to Cease And Desist. https://techcrunch.com/2010/10/24/ubercab-ordered-to-cease-and-desist/. 


\subsection{APPENDIX A}

\begin{tabular}{|c|c|c|c|}
\hline \multicolumn{4}{|c|}{ Parking for Bicycles* } \\
\hline \multirow{2}{*}{\multicolumn{2}{|c|}{ Use }} & \multicolumn{2}{|l|}{ Bike parking requirements } \\
\hline & & Long-term & Short-term \\
\hline \multicolumn{4}{|c|}{ A. COMMERCIAL USES } \\
\hline A.1. & $\begin{array}{l}\text { Eating and drinking estab- } \\
\text { lishments }\end{array}$ & 1 per 5,000 square feet & 1 per 1,000 square feet \\
\hline A.2. & $\begin{array}{l}\text { Entertainment uses other than } \\
\text { theaters and spectator sports } \\
\text { facilities }\end{array}$ & 1 per 10,000 square feet & $\begin{array}{l}\text { Equivalent to } 5 \text { percent of maximum building } \\
\text { capacity rating }\end{array}$ \\
\hline A.2.a & $\begin{array}{l}\text { Theaters and spectator sports } \\
\text { facilities }\end{array}$ & 1 per 10,000 square feet & $\begin{array}{l}\text { Equivalent to } 8 \text { percent of maximum building } \\
\text { occupancy rating } 2\end{array}$ \\
\hline A.3. & Lodging uses & 3 per 40 rentable rooms & $\begin{array}{l}1 \text { per } 20 \text { rentable rooms plus } 1 \text { per } 4,000 \\
\text { square feet of conference and meeting } \\
\text { rooms }\end{array}$ \\
\hline A.4. & Medical services & 1 per 4,000 square feet & 1 per 2,000 square feet \\
\hline A.5. & $\begin{array}{l}\text { Offices and laboratories, research } \\
\text { and develop- ment }\end{array}$ & 1 per 2,000 square feet & 1 per 10,000 square feet \\
\hline A.6. & Sales and services, general & 1 per 4,000 square feet & 1 per 2,000 square feet \\
\hline \multirow[t]{2}{*}{ A.7. } & Sales and services, heavy & 1 per 4,000 square feet & $\begin{array}{l}1 \text { per } 10,000 \text { square feet of occupied floor } \\
\text { area; } 2 \text { spaces minimum }\end{array}$ \\
\hline & B. INSTITUTIONS & & \\
\hline B.1. & Institutions not listed below & 1 per 4,000 square feet & 1 per 10,000 square feet \\
\hline B.2. & Child care centers & 1 per 4,000 square feet & 1 per 20 children. 2 spaces min. \\
\hline B.3. & Colleges & 1 per 5,000 square feet & 1 per 2,500 square feet \\
\hline B.4. & Community clubs or centers & 1 per 4,000 square feet & 1 per 1,000 square feet \\
\hline B.5. & Hospitals & 1 per 4,000 square feet & 1 per 10,000 square feet \\
\hline B.6. & Libraries & 1 per 4,000 square feet & 1 per 2,000 square feet \\
\hline B.7. & Museums & 1 per 4,000 square feet & 1 per 2,000 square feet \\
\hline B.8. & Religious facilities & 1 per 4,000 square feet & 1 per 2,000 square feet \\
\hline B.9. & \multicolumn{2}{|c|}{ Schools, primary and secondary 3 per classroom } & 1 per classroom \\
\hline B.10. & Vocational or fine arts schools & 1 per 5,000 square feet & 1 per 2,500 square feet \\
\hline C. MA & ANUFACTURING USES & 1 per 4,000 square feet & 1 per 20,000 square feet \\
\hline \multicolumn{4}{|c|}{ D. RESIDENTIAL USES } \\
\hline D.1. & Congregate residences ${ }^{3}$ & 1 per sleeping room & 1 per 20 sleeping rooms. 2 min. \\
\hline D.2. & Multi-family structures & $\begin{array}{l}1 \text { per dwelling unit and } 1 \text { per small } \\
\text { efficiency dwelling unit }\end{array}$ & 1 per 20 dwelling units \\
\hline D.3. & Single-family residences & None & None \\
\hline \multicolumn{4}{|c|}{ E. TRANSPORTATION FACILITIES } \\
\hline E.1. & $\begin{array}{l}\text { Park and ride facilities on surface } \\
\text { parking lots }\end{array}$ & At least $20^{5}$ & At least 10 \\
\hline E.2. & $\begin{array}{l}\text { Park and ride facilities in parking } \\
\text { garages }\end{array}$ & $\begin{array}{l}\text { At least } 20 \text { if parking is the principal use of } \\
\text { a property; zero if non-parking uses are the } \\
\text { principal use of a property }\end{array}$ & $\begin{array}{l}\text { At least } 10 \text { if parking is the principal use of a } \\
\text { property; zero if non-parking uses are the } \\
\text { principal use of a property }\end{array}$ \\
\hline E.3. & Flexible-use parking & 1 per 20 auto spaces & None \\
\hline E.4. & $\begin{array}{l}\text { Rail transit facilities and } \\
\text { passenger terminals }\end{array}$ & $\begin{array}{l}\text { Spaces for } 5 \% \text { of projected AM peak period } \\
\text { daily ridership } 5\end{array}$ & $\begin{array}{l}\text { Spaces for } 2 \% \text { of projected AM peak period } \\
\text { daily ridership }\end{array}$ \\
\hline \multicolumn{4}{|c|}{ *Footnote to Table: } \\
\hline \multicolumn{4}{|c|}{ 1) Required bicycle parking includes long-term and short-term amounts shown in this table. } \\
\hline \multicolumn{4}{|c|}{$\begin{array}{l}\text { 2) The Director may reduce short term bicycle parking requirements for theaters and spectator sports facilities that provide bicycle } \\
\text { valet services authorized through a Transportation Management Program. A bicycle valet service is a service that allows bicycles to } \\
\text { be temporarily stored in a secure area, such as a monitored bicycle corral }\end{array}$} \\
\hline
\end{tabular}


3) For residential uses, after the first 50 spaces for bicycles are provided, additional spaces are required at three-quarters the ratio shown in this Table.

4) For congregate residences that are owned by a not-for-profit entity or charity, or that are licensed by the State and provide supportive services for seniors or persons with disabilities, the Director shall have the discretion to reduce the amount of required bicycle parking if it can be demonstrated that residents are less likely to travel by bicycle.

5) The Director, in consultation with the Director of the Seattle Department of Transportation, may require more bicycle parking spaces based on the following factors: Area topography; pattern and volume of expected bicycle users; nearby residential and employment density; proximity to the Urban Trails system and other existing and planned bicycle facilities; projected transit ridership and expected access to transit by bicycle; and other relevant transportation and land use information. 